\title{
Correcciones en la Tragicomedia suscitadas por críticas a la Comedia. Construcción textual de la Comedia inherente a prácticas tradicionales y el apoyo de Cisneros
}

Remedios Prieto de la Iglesia IES «San Juan Bautista». Madrid

Antonio Sánchez Sánchez-Serrano Exprofesor de la Universidad Complutense

RESUMEN

En este trabajo se analizan algunas de las correcciones incluidas en la Tragicomedia encaminadas a acallar críticas que había provocado la Comedia. El análisis permite identificar vestigios de una preexistente "Comedia de Calisto y Melibea» manuscrita, de final feliz y de estirpe humanística que fue "acabada» (reelaborada para la imprenta) por Rojas reorientándola a un final trágico moralizante. Se enfocan aspectos confusos que juzgamos fruto de ese proceso constructivo que advertimos en la Comedia y que, aunque se intentaron aclarar en la Tragicomedia, han generado controversias, tales como la hechicería, disparidades cronológicas, equívocos en los paratextos y autoría. El estudio conduce a establecer cuatro estadios redaccionales básicos reescritos sucesivamente hasta llegar a la versión de 21 autos y a percibir el apoyo de Cisneros a la moralización y publicación de la obra.

Palabras Clave: Celestina, Cisneros, contexto sociocultural, paratextos, refundir, comedia humanística, editor literario, franciscanismo.

Corrections in the Tragicomedia provoked by criticisms of the Comedia. The textual construction of the Comedia as inherent to traditional practices and the support of Cisneros

\section{ABSTRACT}

This paper examines some of the modifications that were included in the Tragicomedia to silence the critics the Comedia had received. The analysis allows to identify some traces of a preexisting handwritten "Comedia de Calisto y Melibea» with a happy ending in the humanistic style, that was «ended» (re-elaborated for the printing press) by Rojas, who also gave it a tragic moralizing end. Some elements difficult to understand that are the result of that process are brought 
into focus. Many of them, despite the clarification attempts of the Tragicomedia, have been the object of controversy, as is the case of the alleged witchcraft, the chronological disparities, and some misunderstandings in the paratexts and authorship. The study leads to establish four phases in the composition that were rearranged one after the other until the known moralizing version in 21 "autos» that received Cisneros's support to be printed.

KeY words: Celestina, Cisneros, socio-cultural context, paratexts, conflation, Humanistic commedy, literary editor, Franciscans.

\section{Preámbulo}

Si bien la Celestina fue objeto de merecida admiración desde su primera versión en 16 autos, la titulada Comedia de Calisto y Melibea, de lo que son prueba las tres ediciones conservadas publicadas en un plazo no superior a tres años, fue también objeto de críticas y controversias según se señala en el Prólogo de la versión ampliada a 21 autos o Tragicomedia de Calisto y Melibea, en el que tras hacerse extensa referencia a contiendas que afectan a casi todos los órdenes de la vida extiende sus efectos a la propia obra: ${ }^{1}$

\section{[...] no quiero maravillarme si esta presente obra ha seýdo instrumento de lid o contienda a sus lectores para ponerlos en differencias, dando cada uno sentencia sobre ella a sabor de su voluntad. Unos dezian que era prolixa, otros breve, otros agradable, otros escura [...]. $\left(\mathrm{a}_{\mathrm{iiij}}{ }^{\mathrm{v}}\right)^{2}$}

Lógico es que la Tragicomedia tratara de corregir los aspectos negativos de tales críticas, especialmente la brevedad y la oscuridad. Se insertaron ochenta y nueve adiciones a lo largo de los 16 autos de la Comedia, según el cómputo de Miguel Marciales (1985: I, 118), amén de la gran adición conocida como "Tratado de Centurio» y agregaciones paratextuales, lo que supone, de acuerdo con Fernando Cantalapiedra (2001: 55-56), un aumento

1.- El Prólogo es atribuible a Rojas (Antonio Sánchez [1985] 1987: 270-275; Antonio Sánchez y Remedios Prieto 1991: 59-62; 2011: 99, 123-126; Bernaldo de Quirós 2017: 145-148).

2.- Transcribimos en cursiva las citas pertenecientes a la Tragicomedia y en letra redonda las pertenecientes a la Comedia y las comunes a ambas versiones. Los números romanos indican los autos y los arábigos las páginas de la edición crítica realizada por José Luis Canet Vallés de la Comedia de Calisto y Melibea (edición de Toledo 1500), que además recoge los cambios de la Tragicomedia incluidos en los dieciséis autos (ediciones de Zaragoza 1507 y Valencia 1514) en notas a pie de página, a las cuales también remitimos consignando la página y la referencia a la nota correspondiente. Cuando las citas de la Tragicomedia se refieren a los paratextos, transcribimos directamente del facsímil de la edición de Juan Joffre, Valencia 1514, indicando su signatura: letra del cuaderno y número de la plana, recto y vuelto. 
del 40\%. Asimismo se realizaron numerosas sustituciones y supresiones. Una suma, según señala Sophie Hirel-Wouts (2017: 51), de 356 cambios.

Parece ser que las modificaciones dieron convincente respuesta a los contemporáneos, pues si relacionamos esas palabras del Prólogo con el hecho de que no se hicieron nuevas ediciones de la Comedia, convendremos en que en la versión ampliada los arreglos resultaron satisfactorios para los lectores y los más de cien editores y traductores de la época antigua. Enrique Fernández (1997) recuerda que en el texto de 21 autos se han identificado 332 sentencias y aporta testimonios del interés que provocaban entre los lectores de los siglos XVI y XVII. Y José Luis Canet (2017c) sugiere una deliberada intención para que el lector reconociera las sentencias y sus procedencias.

Para el lector moderno, por contra, la pertinencia o impertinencia de las innovaciones es tema discutido y discutible. ${ }^{3}$ No pretendemos entrar en el debate. El objetivo del presente trabajo es ofrecer muestras de algunas modificaciones textuales realizadas en los autos de la Comedia y sus paratextos que, a nuestro entender, podrían ayudar a despejar esa «escuridad» aludida en el Prólogo de la Tragicomedia y que en época moderna ha derivado en enfrentados planteamientos. Nos estamos refiriendo a cuestiones como la eficacia o ineficacia de la hechicería, la dicotomía en el tratamiento del tiempo, algún desajuste en la construcción textual, el género literario y la autoría, asunto este de máximo relieve debido a la intelección tan fluctuante que ha provocado la recepción de la Celestina a lo largo del paso de los años: ${ }^{4}$ hasta el siglo xIX nadie en el mundo de la cultura consideró a Rojas creador de la Celestina, mientras que en el siglo XX la mayor parte de la crítica literaria lo elevó a genial creador, si bien en sus últimas décadas ya empezaron a abrirse nuevos cauces de investigación cuya tónica común es la disminución de la preeminencia autorial del Bachiller hasta llegar a minimizarla. ${ }^{5}$

3.- En este aspecto, se hace preciso recordar a Foulché-Delbosc (1900: 45-60), Menéndez Pelayo ([1910] 1962: 260-274), Bataillon (1961), Marciales (1985 I: 63-65), Russell (1978), Sánchez y Prieto (1991: 127-158), Cantalapiedra (2000 y 2001), García-Valdecasas (2000: $107-$ 129), Parrilla (2007), Botta (2007), Bernaldo de Quirós (2010: 24-32; 2011; 2017: 174-186) o Hirel-Wouts (2017).

4.- En cuanto a la problemática de la autoría, citaremos trabajos recientes. José Luis Canet (2017b y 2018) traza de forma precisa la trayectoria que ha llevado la crítica celestinesca desde el siglo xVI al xxI; Bernaldo de Quirós (2017) realiza una exposición crítica de numerosos postulados contrastándolos con el de García-Valdecasas, del que es su infatigable valedor; Remedios Prieto y Antonio Sánchez (2016) estudian las posibles causas que pudieron influir en corrientes de opinión tan opuestas como las habidas entre los siglos XVI-XVIII y XIX-XX. Frente a estos investigadores, Emilio de Miguel Martínez (1996) es, en los últimos años del siglo xx, el más decidido defensor de Fernando de Rojas como único creador.

5.- Progresivamente va incrementándose el número de estudiosos que defienden la dificultad de aceptar a Rojas como creador de la Celestina, ya sea en su totalidad, ya en su mayor parte. Siguiendo un orden cronológico en su punto de partida (muchos de los consignados a continuación han ampliado y matizado posteriormente sus primeros planteamientos), se 
Interpretamos que estos aspectos "oscuros", confusos, se deben, en buena medida, al proceso constructivo que atribuimos a la obra, proceso constructivo que, como ya planteamos en otra ocasión (2016), se incardina en hábitos de composición artística de la época, en prácticas literarias propias de la tradición del libro manuscrito que se extienden hasta muy pasados los primeros tiempos de la imprenta en que aún no se habían fraguado los conceptos modernos de propiedad intelectual y de autoría. Tales como:

a) la utilización de textos de obras previas para componer con ellos obras reorientadas en un nuevo sentido,

b) el derecho que se adjudicaba cualquier propietario de un manuscrito, bien porque se lo hubiera encontrado, bien porque se lo hubieran regalado, cedido, vendido, etc., para intervenir en él y sacarlo a luz mediante la imprenta,

c) el denominar «autor» al responsable de una obra, aunque no fuera su creador/inventor; bastaba con que hubiera intervenido en ella conformándola, dándole el último aspecto y sacado a luz, ${ }^{6}$ e incluso participado «en su génesis, en su corrección, en su primera o segunda redacción, etc.» (Bustos Tauler 2012: 68-69).

Tomando en cuenta este contexto sociocultural, es factible estimar que dichas «oscuridades» tienen su origen, según hemos defendido en tra-

podrían citar a Antonio Sánchez y Remedios Prieto (1971), Cantalapiedra (1979), Marciales (1985), Snow (1999-2000), García-Valdecasas (2000), Ottavio Di Camillo (2001), Bernaldo de Quirós (2005), Westerveld (2005-2009), Canet (2007), Infantes (2010) o Paolini (2011). Esta línea actual de investigación enlaza con la de los epígonos que defendían la anonimia de la Celestina en una época en que ya se preconizaba la genialidad creadora de Rojas: Eggert (1897) y Desdevises du Dezert (1904) creían que Rojas era solo el editor de la Comedia (citados por López Morales 1995: 10, n. 8 y por Westerveld 2009, III, 193-194 y 2013:17-20, quien transcribe el artículo de Eggert, abogando además por la candidatura de Juan del Encina como probable creador de la mayor parte de la Celestina); Foulché-Delbosc (1900: 42) postulaba que Rojas era un autor inventado; Clara Louisa Penney (1954: 11-12) se preguntaba por qué se estaba dando tanto crédito a Rojas como creador de la Celestina y por qué sus contemporáneos no le dieron ninguno, y Sánchez Albornoz en 1956, según anota López Morales (1995: 10, n. 8), proponía que podía tratarse de un homónimo del converso Rojas, postura cercana a la de Canet (2018: 45-52).

6.- Paradigma de lo expuesto es el Amadís de Gaula, fruto de la refundición llevada a cabo por el «autor» Garci Rodríguez de Montalvo a base de reorganizar y reelaborar con cambios, cortes, empalmes y adiciones los tres libros de Amadís ya existentes en estado manuscrito hasta el punto de darles una nueva trama narrativa. También cabe recordar las prácticas dramatúrgicas en el teatro áureo, donde el autor o «ingenio» vendía sus manuscritos al 'autor de comedias' (director/empresario de una compañía teatral) y éste adquiría todos los derechos para modificarlos a su gusto y/o acomodarlos a las necesidades de la puesta en escena, e incluso para venderlos a otro empresario o para imprimirlos. Fenómenos similares acontecían en el teatro europeo (Kevin Perromat 2009). Asimismo, recordemos la reordenación y amplificación por múltiples y sucesivos «autores» de los Flores sanctorum desde su etapa manuscrita medieval hasta el sinnúmero de las versiones impresas del siglo XVI (Aragüés Aldaz 2014). 
bajos anteriores y reformularemos en este con la intención de complementar y actualizar nuestros planteamientos sobre la génesis textual de la Celestina, en la permanencia de diálogos de una comedia preexistente en estado manuscrito, una comedia de filiación humanística completa y consecuentemente de final feliz, titulada ya "Comedia de Calisto y Melibea». Sostenemos que sus magníficos diálogos de realismo estilizado, riqueza léxica, excepcional dominio del lenguaje y precisas acotaciones implícitas en los diálogos ${ }^{7}$ fueron utilizados por Rojas para componer la reprobadora tragedia que sorprendentemente conservó el mismo título de "Comedia» en la primera versión impresa de 16 autos. De esta manera, el Bachiller Fernando de Rojas habría «acabado» (= dado la última mano, compuesto, reordenado, refundido, adaptado) la precedente "Comedia de Calisto y Melibea» manuscrita mediante procedimientos compositivos como interpolaciones, supresiones, sustituciones, fusiones y transposiciones textuales, y reemplazado el final feliz por un desenlace amargo, desastrado y por ende moralizante. O dicho de otra forma: nuestra propuesta es que la contribución de Fernando de Rojas a la composición de la versión en 16 autos consistió en convertir una comedia de raigambre humanística corrigendo mores («fecha en aviso de los engaños de las alcahuetas y malos y lisonjeros sirvientes» [177]) en una tragedia reprobatio amoris ("compuesta en reprehensión de los locos enamorados que, vencidos en su desordenado apetito, a sus amigas llaman y dizen ser su dios» [177]) y prepararla para la imprenta. A su vez, esa comedia manuscrita de final feliz tendría raíces italianas y se habría hecho teniendo como base las "razones del antiguo auctor», que «estaban por acabar» en un manuscrito anónimo («los papeles» del «antiguo auctor») según informa la Carta; Carta que estimamos redactada en su mayor parte por el autor de la comedia corrigendo mores de final feliz y no por Rojas, a quien vemos como el «amigo» que la recibe junto con la obra literaria que después refundirá — pensamos que potenciado por personas notables del ámbito de Cisneros como el humanista Proaza ${ }^{8}$ dándole una nueva trama argumental con sentido diferente. Así pues, el que la Celestina se hubiera formado por recontextualización de textos anteriores sería un factor que explicaría la anonimia de la Celestina durante los siglos XVI-XVIII (Antonio Sánchez y Remedios Prieto 1991; 2011: 99-103, 123-127; 2016).

7.- No nos estamos refiriendo aquí a los fragmentos que detienen desmesurada e inútilmente la acción, de largos periodos sintácticos y abundante adjetivación que con tanto detenimiento ha analizado Bernaldo de Quirós (2005, 2008, 2009, 2010, 2011, 2012, 2017).

8.- Nos resulta difícil identificar a Proaza con un simple corrector de imprenta según se ha venido repitiendo frecuentemente. Proponemos que sus octavas responden a la aprobación o censura aprobatoria que ya presentan muchos de los libros en letras de molde, incunables y post-incunables, antes de que la Pragmática de los Reyes Católicos de 1502 la exigiera para poderlos vender. El clérigo y humanista Proaza habría sido el censor de la obra por delegación del Arzobispo de Toledo, el futuro Cardenal Cisneros (Antonio Sánchez y Remedios Prieto 2011: 120-126; Remedios Prieto 2014: 117-121; Antonio Sánchez 2014: 138-140). 
Otros postulados modernos alejados de las corrientes de crítica celestinesca arraigadas en el siglo xx integran elementos coincidentes con los nuestros.

Así, Cantalapiedra Erostarbe (1979, 1986, 2000, 2011, 2016), García-Valdecasas (2000) y Bernaldo de Quirós (2005, 2008, 2009, 2011, 2012, 2015, 2017) sostienen que Rojas no fue un creador sino un refundidor de una obra extensa con raíces italianas y manuscrita, aunque incompleta. Según Cantalapiedra, esa obra anterior, que se extendería por los doce primeros autos de la Celestina, sería una comedia terenciana sobre la que Rojas «añadió, eliminó, modificó, diseminó y acabó su tragedia humanística» (2016: 9). Según García-Valdecasas y Bernaldo de Quirós, el Bachiller habría intervenido en una obra teatral representable al estilo italiano, que abarcaría los catorce autos primeros, básicamente añadiendo sentencias, frases amplificadoras, citas de textos literarios y alusiones mitológicas sin apenas realizar otro tipo de manipulaciones compositivas en el texto encontrado.

Joseph T. Snow (2005-2006) muestra cumplidamente la anonimia de la Celestina durante los siglos XVI-XVIII. Canet (2007, 2008, 2011:11-13, 21-22, 29, 47-53; 2017b: 22-23, 31-32, 36-40; 2018: 36) juzga verosímil que antes de la Comedia de Calisto y Melibea impresa en 16 autos existiera otra, breve, con el mismo título y similar a las comedias humanísticas, corrigendo mores y con final feliz, cuya ampliación y transformación en tragedia reprobatio amoris habría realizado un colectivo de profesores universitarios e intelectuales acordes con el reformismo cristiano propiciado por el Cardenal Cisneros (entre quienes se encontraba Alonso de Proaza), siendo «posible que [Rojas] haya participado en su versión definitiva: de ahí la frase aparecida en los acrósticos de que 'acabó' la obra, es decir, le dio 'la última mano', según ha detallado Joseph T. Snow» (2007: 43; 2011: 19; 2017b: 29). En consecuencia, Canet edita la Comedia (2011) sin el nombre de Rojas en la portada y la Tragicomedia con el nombre del Bachiller entre signos de interrogación (2017c). Ottavio Di Camillo $(2010,2012)$ y Devid Paolini (2011, $2012,2017)$ no dudan de un núcleo italiano, dadas las fuentes de esta procedencia existentes en la Celestina y desconocidas en España cuando se estampó la obra por primera vez. Di Camillo (2001: 111-116) y Canet (2007: 38-39; 2017b: 33) estiman que la Carta no procede de la pluma de Rojas.

Según puede observarse, una diferencia sustancial entre estos postulados y los nuestros estriba en, como escribiera Joseph T. Snow en el Prólogo a nuestro libro (1991: v), "la existencia de otro autor, intermedio entre el primitivo (el del manuscrito o primer esbozo de la obra) y Rojas». Patrizia Botta apunta a nuestra tesis al afirmar en su estudio sobre la $\mathrm{Ce}$ lestina de Palacio (1997):

[...] no andaríamos lejos del 'autor intermedio', padre de un texto entero, supuesto en el reciente trabajo [de 1991] de Sánchez Sánchez-Serrano y Prieto de la Iglesia 
(si bien estos pensaban en una comedia de final feliz que, con los datos que tenemos actualmente a mano, no es probable que haya existido) [...]. [Rojas] lo va puliendo $y$ retocando en todas sus partes, incluido sobre todo el $1^{\circ}$ Auto. [Rojas] es, pues, autor de la 'nueva' Celestina, autor integral del principio hasta su fin, autor de su forma fijada para la imprenta, la primera en 16 autos, de la que es responsable único y cabal. (1997: 147)

Suscribiríamos estas palabras de tan destacada celestinista si no fuera por sus reservas acerca de la precedencia de una comedia de final feliz. Desde 1971 lo venimos defendiendo, si bien ha sido en nuestro artículo de 2017 publicado en eHumanista 35 donde de modo especial hemos puesto de relieve diálogos de la "forma fijada para la imprenta» de 16 autos en los cuales es factible detectar vestigios de esa preexistente comedia manuscrita de final feliz que preconizamos y cuya paternidad correspondería a ese "autor intermedio».

Como mínima muestra de esos vestigios sirva ahora uno que se encuentra en el Auto XIV de la Comedia y que fue suprimido sagazmente en la Tragicomedia, lo que, además, da idea de que los diálogos reutilizados por Rojas no abarcan solamente el actual Auto I, según es creencia muy extendida, sino mucho más. Fijémonos en lo que dice Melibea a Calisto tras consumarse el primer encuentro amoroso en el huerto:

MelibeA.- Señor, por Dios, pues ya todo queda por ti, pues ya soy tu dueña, pues ya no puedes negar mi amor, no me niegues tu vista de día passando por mi puerta; de noche donde tú ordenares. (XIV, 331-332, énfasis añadido)

La frase enfatizada resultaría desconcertante, "escura», para cualquier atento y advertido lector de la Comedia pues esa ida «de noche donde Calisto ordenare» sería imposible para la "encerrada doncella» (X, 291, 297) hija del "noble y esforzado» Pleberio y de la "celosa y brava» Alisa (III, 221). La Tragicomedia hace la corrección adecuada: "Mas las noches que ordenares sea tu venida por este secreto lugar a la mesma hora [...]" (XIV, 332, n. a). Por cierto que la Tragicomedia suprime también «de día passando por mi puerta», supresión acertada ya que al final del Auto XIII de la Comedia, Calisto, tras conocer la muerte de sus criados y a fin de justificar su falta de reacción ante las ejecuciones, se había hecho esta reflexión: «Mañana haré que vengo de fuera, si pudiere vengar estas muertes; si no, pagaré mi innocencia con mi fingida absencia» (XIII, 327). El mantenimiento de la petición de Melibea implicaría que Calisto hubiera de desatenderla después de su logro amatorio, o bien ser visto en la ciudad por tanta gente como ya conocía su relación con los muertos por haberla voceado el verdugo y Elicia (XIII, 325-326). 
Como es sabido, los paratextos también sufrieron cambios. En la segunda parte del presente trabajo nos detendremos en aquellas modificaciones que pueden aportar luz a los problemas relativos al proceso de construcción textual, género literario y autoría de la Celestina.

\section{I.- Algunos aspectos oscuros en autos de la Comedia. Función correctora de modificaciones en la Tragicomedia}

\section{Los pretendidos poderes satánicos de Celestina. Fallas significativas en la construcción del texto}

En los autos III, IV y V encontramos discordancias u "oscuridades» que parecen consecuencia de la reutilización de los diálogos de una obra previa del género cómico para componer con ellos, y naturalmente con algunas alteraciones, una historia diferente. Leemos en el Argumento general:

[Calisto] fue preso en el amor de Melibea, muger moça muy generosa, ${ }^{9}$ de alta y sereníssima sangre, sublimada en próspero estado, una sola heredera a su padre Pleberio y de su madre Alisa muy amada. (177)

Si tenemos en cuenta esta descripción, produce perplejidad que Alisa - la madre de una joven de tan elevado rango social-, tras escuchar las severas advertencias de Lucrecia sobre la vieja que «vendía las moças a los abades y descasava mill casados» (IV, 227) y conociendo sus dañinas habilidades por haber sido antigua vecina (IV, 226, 228-231; VI, 254, X, 298), acepte su visita brindándole la entrada complacida y risueña, y emplee un registro lingüístico vulgar acorde con los de la alcahueta, Elicia y Areúsa: ${ }^{10}$

AlisA.- ¡Hi, hi, hi ! ¡Mala landre te mate si de risa puedo es$\operatorname{tar}[\ldots]$ ! Ya me voy recordando d'ella; una buena pieça. No me digas más; algo me verná a pedir. Di que suba. (IV, 227)

y además decida ausentarse dejando a su hija con aquella e incluso recomendándola abiertamente:

AlisA.- Hija Melibea, quédese esta muger honrrada contigo, que ya me parece que es tarde para yr a visitar a mi hermana [...] que desde ayer no la he visto. [...] Pues, Melibea, contenta a la vezina en todo lo que razón fuere darle por el hilado [...] (IV, 228, énfasis añadido)

9.- "Generosa»: Noble y de ilustre prosapia (DA)

10.- Expresiones vulgares del tipo «mala landre te mate» las emplean Areúsa (VII, 265, 267), Elicia (I, 193; IX, 285) y Celestina (I, 204; XII, 317). 
Hemos enfatizado este último vocablo, "hilado», por su valor anfibológico. Sus connotaciones «lascivas rientes» encajan con propiedad en el marco del género de la comedia humanística. Como han señalado varios investigadores, hilado, hilar, urdir, tela y otras labores de producción de tejidos eran, en la literatura y en la vida, metáforas referidas a la relación sexual (Remedios Prieto y Antonio Sánchez 2017: 387-392). Sin alejarnos de la Celestina, así lo demuestran estas palabras eufemísticas, teñidas de intenso humor erótico, de la alcahueta que poco antes había dirigido a Sempronio caminando por la calle:

Celestina.- [...] Pocas vírgines, a Dios gracias, has tú visto en esta ciudad que ayan abierto tienda a vender, de quien yo no aya sido_corredora de su primer hilado [...]. (III, 218219 , énfasis añadido)

De todo esto se deduce que en la subyacente comedia corrigendo mores de final feliz era la propia madre — que había «urdido una tela» según palabras de Lucrecia, con toda la carga peyorativa y sexual que puede adquirir esta expresión en un marco lúdico-la que buscaba propiciar esta conversación de su hija con la alcahueta, estrategia nada insólita en la comedia romana ni en el género de la comedia humanística donde a veces son las propias madres quienes provocan o consienten los deslices de sus hijas. ${ }^{11}$

Sin embargo, este comportamiento de Alisa resulta incompatible con el Argumento general y la trama argumental de la Celestina, y la solución que nos ofrece la obra para justificar esta actitud casi cómplice de Alisa con la tercera es fundamentarla en la intervención del diablo. ${ }^{12}$ En efecto, murmura Celestina: "Por aquí anda el diablo aparejando oportunidad, arreziando el mal a la otra» (IV, 228), frase que en la Tragicomedia se refuerza añadiéndole esta otra dirigida directamente al diablo: " $E a$, buen amigo! ;Tener rezio! Agora es mi tiempo o nunca. No la dexes, llévamela de aquí a quien digo.» (IV, 228, n. a).

11.- Lida de Malkiel (1962: 490 y 492) señala que en la comedia romana no es raro que la madre de la enamorada sea su medianera (Asinaria, Cistellaria) o esté al tanto de los deslices de su hija (Adelphae, Hecyra). También indica que hay madres que trafican con sus hijas, como en las comedias humanísticas Paulus y Poliodorus, en donde la madre, con el pretexto de visitar a una vecina enferma, deja a la hija sola con el amante. Lida, desde su perspectiva honesta de considerar a Alisa como la madre honorable que corresponde a la Melibea del Argumento general, no le ve parecido alguno con las de las comedias citadas. Para nosotros, son un directo precedente con significativas similitudes respecto a esta Alisa del Auto IV de la Celestina. También Gerli (1995) percibe complicidad entre las dos mujeres, así como Cantalapiedra (2006). Canet (2007: 35- 37; 2011: 31-46) compara cumplidamente las comedias humanísticas Poliscena y Poliodorus con la Celestina.

12.- Numerosos estudiosos ven la eficacia de una philocaptio. Ana Vian Herrero (1990) ofrece una visión de conjunto. Ximena Gómez Goyzueta (2017) sintetiza una panorámica de las hipótesis de diversos celestinistas en pro y en contra de la supuesta eficacia del conjuro y expone su propia contribución desde el punto de vista de la retórica del lenguaje. Canet (2017c) aporta claves interpretativas del texto según se admita o no la influencia del conjuro. 
Así pues, esta intervención diabólica, seguramente inexistente o por lo menos inoperante y desenfadada en la comedia original manuscrita según se deduce de la Carta avisando contra "falsas mugeres hechizeras» (171) y de la información de Pármeno a Calisto sobre las fingidas artes hechiceriles de la alcahueta — «Pintava figuras, dezía palabras en tierra. ¿Quién te podrá dezir lo que esta vieja fazía? Y todo era burla y mentira» (I, 199) —, se convierte en elemento esencial para la Celestina. Se hacía necesario, por tanto, cimentar esa intervención diabólica con un conjuro que la propiciase. Y esto exigía la vuelta de la tercera a su casa inmediatamente después de haber estado en la de Calisto, cosa que no ocurriría en la comedia corrigendo mores manuscrita. Tanto en la Comedia como en la Tragicomedia, la secuencia de Celestina en su casa para realizar el conjuro presenta no pocas "oscuridades» en la construcción textual, dado que los diálogos entre la vieja y Sempronio, con sus excelentes acotaciones implícitas, los muestran caminando por la calle y a Celestina resuelta a ir directamente a casa de Melibea sin pasar previamente por la suya.

Ciertamente, basándonos literal y estrictamente en los diálogos, queda claro, por las expresiones que utiliza Sempronio, que este alcanza a Celestina en plena calle, cerca, incluso, de la casa de Calisto:

Sempronio.- ¡Qué espacio lleva la barvuda! ¡Menos sosiego traýan sus pies a la venida [...] ¡Ce! Señora Celestina, poco has aguijado. (III, 217)

Y continúan andando y charlando ampliamente por el camino hasta que la vieja se despide de él:

\section{Celestina.- [...] A casa voy de Pleberio. Quédate a Dios. [...] (III, 220)}

No obstante, esta despedida no se cumple a pesar de insistir en su decisión de ir directamente a casa de Melibea y llevar previsoramente "un poco de hilado» en su faltriquera:

Celestina.- [...] Y con esto que sé cierto, voy más consolada a casa de Melibea [...] Aquí llevo un poco de hilado en esta mi faltriquera, con otros aparejos que comigo siempre traygo, para tener causa de entrar donde mucho no soy conoscida la primera vez. [...] (III, 221).

Si se hubiera llevado a efecto la despedida, Celestina no habría vuelto a su casa y el conjuro obviamente no lo hubiera realizado. Sin embargo, pese a esta despedida, la charla de camino continúa entre la envalentonada vieja y el temeroso criado y a donde llegan no es a casa de Pleberio sino a la de la alcahueta, como nos lo indican las palabras de una sorprendida Elicia: «iSantiguarme quiero, Sempronio! [...] ¿Qué novedad 
es esta, venir hoy acá dos vezes?» (III, 221) ${ }^{13}$. La discordancia entre los diálogos y la acción es un fallo constructivo que apunta a que, en la comedia manuscrita de estirpe humanística, el episodio en torno del conjuro en casa de Celestina no existía tal como lo encontramos publicado, que este episodio es fruto de una manipulación posterior conducente a la transformación en tragedia. ${ }^{14}$

En verdad, es una solución técnica poco ortodoxa para hacer posible esa vuelta de Celestina a su casa, tan necesaria para la realización del conjuro; pero un arreglo más adecuado habría requerido una modificación bastante profunda de los diálogos. No bastaría con suprimir la frase de despedida «A casa voy de Pleberio. Quédate a Dios» por dos razones. Primera, porque la secuencia en casa de Celestina rompe la lógica concatenación espacio-temporal y temática que hubiera existido entre los temores de Sempronio manifestados a Celestina en plena calle (III, 221) y los de esta cuando, ya sin compañía, continúa su andadura a casa de Pleberio:

Celestina.- Agora que voy sola, quiero mirar bien lo que Sempronio ha temido d'este mi camino. [...] Que, aunque yo he disimulado con él, podría ser que si me sintiesen en estos passos de parte de Melibea, que no pagasse con pena que menor fuesse que la vida [...] Pues, jamargas cient monedas serían estas! ¡Ay, cuytada de mí [...]! (IV, 225)

Y segunda razón, porque los diálogos del Auto V nos muestran también que el reencuentro entre la alcahueta y Sempronio tiene lugar en la calle y, presumiblemente, en el mismo sitio en que se había producido esa despedida que en la Celestina ha quedado anulada pero que sería efectiva en la comedia preexistente manuscrita. Sus precisas acotaciones implícitas en los diálogos no dejan lugar a dudas de que en esta ocasión también se encuentran en la calle y que van juntos directamente a casa de Calisto:

13.- Esta despedida fallida sugirió a Marciales (1985, II, 67-68 n. 25) que es un resto de una redacción anterior inédita, que la escena o acto terminaba en el punto de la despedida y que Rojas alargó, interpolándolo en el texto anterior, gran parte del parlamento de Celestina. Russell (2001: 287, n. 42), aunque considera factible esta opinión de Marciales, piensa que esta frase de despedida sirve simplemente para ilustrar la locuacidad de la vieja. Lobera et alii (2000: 102 y 414; 2011: 102 y 622) apoyan la hipótesis de Russell y nosotros, sin negar la locuacidad de Celestina en este pasaje y en toda la obra, también la apoyaríamos si no fuera porque los efectos de esa despedida no se cumplen puesto que el criado y la alcahueta no se separan, ella no va a casa de Pleberio sino a la suya propia acompañada de Sempronio.

14.-Defendemos que esta secuencia es fruto de una intervención posterior en el manuscrito, en Antonio Sánchez Sánchez-Serrano [1985] 1987: 255-259 y en nuestros posteriores trabajos de 1991: 96-101; 2009: 147-153; 2017: 389-391. Otros estudiosos también perciben manipulaciones en este episodio. Así, García-Valdecasas (2000: 256-260, 348-349) llega a una conclusión cercana a la nuestra; Marciales (1985: II, 71) y Cantalapiedra (2000: II, 379) consideran que el conjuro, basándose en la circunstancia de que los conjuros se hacían y hacen de noche, es un añadido a la redacción primitiva. Bernaldo de Quirós (2010: 137 n. 277; 2012: 186-187; 2017: 36 n.100) ve en el conjuro alguna adición o al menos retoques de Rojas. 
Sempronio.- O yo no veo bien o aquella es Celestina. ¡Válala el diablo, haldear que trae! Parlando viene entre dientes. ]...] ¿Quién jamás te vido por la calle, abaxada la cabeça, puestos los ojos en el suelo, y no mirar a ninguno como agora? ¿Quién te vido hablar entre dientes por las calles y venir aguijando [...]? [...] que desde que dio la una te espero aquí y no he sentido mejor señal que tu tardança. [...] Por amor mío, madre, no passes de aquí sin me lo contar.

Celestina.- Sempronio, amigo, ni yo me podría parar ni el lugar es aparejado. Vente comigo delante Calisto, oyrás maravillas [...] $(\mathrm{V}, 242)$

Por último, percatémonos de que si las soluciones que presentan los parlamentos no son buenas, peores son los Argumentos o sumarios que encabezan los autos III y V, que parecen destinados a condicionar la intelección de los lectores en el sentido de que acepten la vuelta de Celestina a su casa para realizar el conjuro:

Argumento del tercero auto. Sempronio vase a casa de Celestina, a la qual reprende por la tardança. Pónense a buscar qué manera tomen en el negocio de Calisto con Melibea. En fin sobreviene Elicia. Vase Celestina a casa de Pleberio. Queda[n] Sempronio y Elicia en casa. (III, 217)

Según puede observarse, tal redacción es discordante con los diálogos. Como ya vimos, cuando Celestina se despide de Sempronio en la calle diciendo "A casa voy de Pleberio. Quédate a Dios» no sucede tal cosa, sino que ambos siguen charlando mientras caminan y llegan ja casa de Celestina!

El Argumento del Auto V tampoco concuerda con los diálogos de dicho auto:

Argumento del ouinto auto. Despedida Celestina de Melibea, va por la calle hablando consigo misma entre dientes. Llegada a su casa, halló a Sempronio que le aguardava. [...] $(\mathrm{V}, 241)$

Como es obvio, Celestina no "halló a Sempronio que la aguardaba en su casa», sino que se encontraron en la calle. ${ }^{15}$ Se evidencian así unas

15.- La influencia de los Argumentos en la percepción de algunos lectores es evidente. Así se puede corroborar en una extensa gama que va desde valiosos estudios de reconocidos celestinistas (Luis Rubio García 1985: 135; Florencio Sevilla 2009: 201) hasta ediciones escolares de la Celestina (María del Socorro Alcalá Iberri 2013: 28; Eduardo Alonso 2016: 101), pasando por adaptaciones teatrales (Luis Escobar y Pérez de la Ossa 1959: 33-36; Torrente Ballester 1988: 38-39 y Casona 1966 [citado por María Bastianes 2017: 240]) y teatro para programas de TVE (José Vila Selma 1967). 
contradicciones bastante elocuentes entre los Argumentos de los autos y sus diálogos. Los lectores reflexivos debieron de quedarse desconcertados. Y es esta una de las cuestiones que trata de resolver el Prólogo de la Tragicomedia al desentenderse su autor de los sumarios y responsabilizar a los impresores:
que aun los impressores han dado sus punturas, poniendo rú- bricas o sumarios al principio de cada auto, narrando en breve lo que dentro contenía, una cosa bien escusada según lo que los antiguos scriptores usaron. $\left(\mathrm{a}_{\text {iiij }} \mathrm{r}\right)$

Sin embargo, aunque denuncia la intervención de los impresores por haber introducido los sumarios, no censura la descoordinación entre los hechos que narran y la realidad de las acciones dialogadas contenidas en los respectivos autos.

Ante todo lo expuesto, cabe preguntarse por qué, si se acometieron una suma tan elevada de modificaciones en la Tragicomedia que superan el número de 350, no se corrigieron estos Argumentos conformándolos con la realidad de los diálogos. Quizá fuera porque se ajustan mejor que los diálogos a la trama argumental de la tragedia. De todas maneras vislumbramos en ello cierta intencionalidad de encauzar la mente del lector hacia una influencia demoníaca que justificara la extraña actitud de Alisa además del brusco cambio de Melibea en su apreciación por Calisto y su distorsionada percepción de la realidad temporal. ${ }^{16}$ Las adiciones de la Tragicomedia van en este sentido: se amplía el conjuro con unas cinco líneas $(222, n$. b), se incrementan dos apartes en que la alcahueta se dirige expresamente al diablo (IV, 228 n. a; 233 n. f) y, en la descripción que Celestina realiza de la reacción de Melibea al oír el nombre de Calisto, se interpolan unos siete renglones que la presentan como auténtica endemoniada:

CelestinA.- [...] Y empos desto, mil amortescimientos y des-
mayos, mil milagros y espantos. Turbado el sentido, bulliendo
fuertemente los miembros todos a una parte y a otra, herida
de aquella dorada flecha que del sonido de tu nombre le tocó,
retorciendo el cuerpo, las manos enclavijadas como quien se
despereza, que parecia que las despedaçava, mirando con los
ojos a todas partes, coceando con los pies el suelo duro. [...]
(VI, 249 n. c)

16.- En este sentido es imprescindible recordar la ya clásica aportación de Peter E. Russell "La magia, tema integral de La Celestina» (1978). Según este ilustre hispanista (y con él otros como Petriconi, Maravall, Patrizia Botta o Dorothy S. Severin), la repentina y violenta pasión amorosa de Melibea y su desorientación del paso del tiempo serían consecuencias de la philocaptio diabólica. Para nosotros (1991: 114-125; 2009, 2017), ese repentino y violento cambio psicológico de Melibea se debería a los procedimientos compositivos practicados por Fernando de Rojas, quien habría trazado la figura de Melibea fundiendo dos personajes femeninos distintos procedentes de la comedia corrigendo mores de final feliz. 


\section{Unas acotaciones acertadamente interpoladas}

En el Auto VI existe un arreglo textual que si bien carece de importancia para la comprensión de la obra, vale como testimonio de esa función correctora de errores o inadvertencias anteriores que atribuimos a la Tragicomedia.

Cuando en el Auto VI Celestina, tras haberse entrevistado con Melibea, le ha adelantado a Calisto que "el fin de su razón y habla fue muy bueno" (VI, 247), el joven, aliviado e interesado, invita a la alcahueta a subir con él a su cámara para que detalle allí su relato: "En mi cámara me dirás por estenso lo que aquí he sabido en suma»(VI, 247). Es lógico pensar que esa subida a su cámara no tendría más objeto que quedarse a solas con la tercera. No obstante, cuando Celestina en su relato le dice que el motivo de entrada en casa de Melibea fue "vender un poco de hilado, con que tengo caçadas más de treynta de su estado [...] y algunas mayores» (VI, 248) - descripción que no cuadra en absoluto con la Melibea «de alta y serenísima sangre, sublimada en próspero estado» que nos presenta el Argumento general -, Calisto replica:

CAListo.- Esso será de cuerpo, madre, pero no de gentileza, no de estado, no de gracia y discreción, no de linaje, no de presumpción con merescimiento, no en virtud, no en habla. (VI, 248)

Y sorprendentemente, por lo dicho más arriba sobre la privacidad que busca Calisto aislándose de sus criados, lo que se lee a continuación es un comentario despectivo de Pármeno que indica que estos están presentes: « $i$ Ya escurre eslavones el perdido, ya se desconciertan sus badajadas! Nunca da menos de doze [...]»(VI, 248). Pero en la Tragicomedia, tras la invitación de Calisto a Celestina de subir a su cámara, se introduce un pasaje que con sus acotaciones descriptivas del movimiento de los personajes justifica la presencia de los criados:

Pármeno.- ;O Santa María! Y qué rodeos busca este loco por huyr de nosotros [...] sin que esté presente quien le pueda dezir que es prolixo. ¡Pues mándote yo, desatinado, que tras ti vamos! Calisto.- Mira, señora, qué hablar trae Pármeno, como se viene santiguando de oýr lo que has hecho de tu gran diligencia [...] Sube, sube, sube y assiéntate, señora. (VI, 247, n. a)

Así pues, aquí encontramos un nuevo ejemplo de esa función de corrección de fallas anteriores que a veces ejerce la versión Tragicomedia. 


\section{Un llamativo desajuste entre el tiempo representado y el no representado enmendado en la Tragicomedia}

Otro arreglo textual está vinculado al problema del tratamiento del tiempo.

En la primera visita de Celestina a Melibea (Auto IV), la joven no parece sentir angustia alguna por el amor de Calisto. Es más, cuando oye su nombre se irrita y alude a él con apelativos ridiculizantes: «loco saltaparedes, fantasma de noche, luengo como ciguñal, figura de paramento mal pintado" (IV, 234), y se aplaca cuando Celestina le aclara que solo pretende de ella una oración a santa Polonia y su cordón-ceñidero que «ha tocado todas las reliquias que ay en Roma y en Hierusalem", como remedio para el «dolor de las muelas» (IV, 235) que supuestamente le aquejaba desde hacía ocho días. Como la oración no puede ser escrita en el transcurso de la visita, Celestina se lleva el cordón y queda en volver por aquella en el día siguiente (IV, 237). Sin embargo, ese día siguiente Lucrecia va en busca de Celestina para que visite urgentemente a su señora "porque se siente muy fatigada de desmayos y dolor del coraçón» (IX, 290).

El Auto X comienza con los lamentos de una Melibea angustiada y abatida por una terrible pasión amorosa mientras espera con ansiedad a Celestina:

MelibeA.- ¡O lastimada de mí! [...] ¿Y no me fuera mejor conceder su petición y demanda ayer a Celestina, quando de parte de aquel señor, cuya vista me cativó, me fue rogado, y contentarle a él y sanar a mí [...]? (X, 291, énfasis añadido)

Diríase que Melibea está recordando una entrevista muy diferente ya que los supuestos ruegos de Calisto que le transmite Celestina habían quedado satisfechos «ayer»: el cordón entregado y la oración escrita prometida para el día siguiente.

Verdad es que ese mal de Calisto que había descrito Celestina, "derribado [por] una sola muela» (IV, 237), pudo haberlo interpretado Melibea como síntoma de enamoramiento según el argot popular ${ }^{17}$ y que ello produjera también amor en ella; pero lo cierto es que eso habría ocurrido

17.- Señalan el valor eufemístico del sintagma «dolor de muelas» como mal de amores o enamoramiento apasionado, entre otros estudiosos, James R. Stamm (1988: 93), Miguel GarciGómez (1994: 200) y Louise Vasvari (2009), quien revisa su significado sexual-erótico en la literatura oral y en el folclore. Por su parte, María Eugenia Lacarra Lanz (1990: 176) destaca la comicidad de dicha expresión por su doble sentido, el honesto y el sexual, ya que "desde muy temprano en la Edad Media se comparaba el dolor de muelas con el exceso de pasión amorosa»; algo semejante se desprende de que el cordón, símbolo de entrega amorosa, haya «tocado todas las reliquias» por haber estado en contacto con su cuerpo, es decir, con lo más sagrado de una joven virgen. Estas dilogías añaden tinte humorístico-lascivo al fragmento. También puede verse Lobera et alii 2000: 129, 622-623; 2011: 129, 831. 
"ayer», mientras que los males de Melibea y la estructura verbal de sus propias palabras sugieren plazos de tiempo mucho más dilatados:

Melibea.- [...] Mi mal es de coraçón. [...] que no pensé jamás que podía dolor privar el seso como este haze; túrbame la cara, quítame el comer, no puedo dormir, ningún género de risa querría ver [...] (X, 293)

En cuanto a la causa de sus males, lo que expone Melibea parece relacionado con la interpretación del «dolor de muelas» que acabamos de formular como mal de amores:

MelibeA.- [...] la alteración que tú me causaste con la demanda que sospeché de parte de aquel cavallero Calisto, quando me pediste la oración. (X, 293)

Se hace difícil de aceptar (si no se admite la philocaptio, como es nuestra postura por lo expuesto anteriormente) que todos esos síntomas de Melibea estén referidos a lo acontecido entre «ayer» $\mathrm{y}$ "hoy» $\mathrm{y}$, en todo caso, que la llamada urgente a Celestina se debiera a las angustias de un solo día. Tropezamos así con el problema del desarrollo del tiempo, quizás uno de los más estudiados y discutidos de la Celestina. Es obvio que el problema del tiempo carecía de arreglo posible en la Tragicomedia sin hacer complejos cambios en los diálogos que conforman la Comedia. Lo que sí se enmienda es el desajuste a que acabamos de referirnos de la no fundamentada llamada urgente a la tercera: se enmienda sustituyendo una corta intervención de Lucrecia sin alcance temporal dilatado - "Antes que agora lo he sentido y me ha pesado» (X, 298) - por esta otra con unas palabras que convierten en habituales los males descritos por Melibea y que Lucrecia tiene observados desde "mucho antes que agora»:

LUCRECIA.- Señora, mucho antes de agora tengo sentida tu llaga y calado tu desseo. Hame fuertemente dolido tu perdición. Quanto tú más me querías encobrir y celar el fuego que te quemava, tanto más tus llagas se manifestavan en la color de tu cara, en el poco sossiego del coraçón, en el meneo de tus miembros, en comer sin gana, en el no dormir. Assí que contino se te caýan como de entre las manos señales muy claras de pena. [...] Çofría con pena, callava con temor, encobría con fieldad [...] (X, 298 n. c)

Lo que, a fin de cuentas, viene a poner de manifiesto que los tres días sucesivos más unas horas del amanecer del cuarto en que según el encadenamiento cronológico de la acción dialogada se desarrolla la Comedia, resultaban un marco muy estrecho y era necesario en numerosas ocasiones prescindir mentalmente de ese tiempo cronológico y real representado. De aquí que sea lógico que Joseph T. Snow $(2010,2017,2018)$ pueda 
hablar de un «tiempo real no representado inferido del texto dialogado» o «tiempo en off» ${ }^{18}$ que nosotros estimamos consecuencia de la fusión en una sola de dos acciones amorosas de distinta índole y distanciadas en el tiempo, las cuales conformarían la preexistente comedia corrigendo mores manuscrita de final feliz (Remedios Prieto y Antonio Sánchez 2017).

\section{II.- Algunas modificaciones correctoras en los paratextos de la Tragicomedia}

Nos ocuparemos ahora de los paratextos considerándolos elementos con finalidad comunicativa, pues aunque ciertamente reflejan convenciones retóricas y tópicos de la época no es menos cierto que transmiten un mensaje con información que afecta a la autoría, génesis de la obra, propósitos y causas de su realización. Enfocaremos algunas de las modificaciones más relevantes que apuntan hacia esta dirección.

\section{La Tragicomedia corrige la rúbrica de la Carta de la Comedia}

En la Comedia (Toledo 1500 y Sevilla 1501), la Carta va precedida por la rúbrica "El autor a un su amigo» (171); en las ediciones tempranas de la Tragicomedia (a excepción de la traducción al italiano de 1506 y la edición de Zaragoza 1507) se cambia por «El auctor a un su amigo» $\left(\mathrm{a}_{\mathrm{i}}{ }^{\mathrm{v}}\right) .{ }^{19}$

Tomaremos como referencia la edición de Valencia 1514 por haber sido estimada tradicionalmente como la mejor ${ }^{20}$ y por constatarse en ella la intervención de Proaza. Si bien la crítica ha dedicado considerables pá-

18.- Joseph T. Snow (2010) contrasta distintas posturas de la crítica (Menéndez Pelayo, Bonilla y San Martín, Cejador, Asensio, Gilman, Lida de Malkiel) ante el problema del tiempo en Celestina y aboga por la existencia de un «tiempo real inferido del espacio textual» a la vista de las numerosas referencias temporales de larga duración como esta de Lucrecia fruto de las correcciones llevadas a cabo en la Tragicomedia y que Snow califica de «clave imprescindible para establecer la cronología de las acciones en la Tragicomedia» (2018: 275). Con el fin de solucionar las discrepancias entre el tiempo representado y las alusiones a lapsos largos de tiempo, argumenta que desde que Melibea vio a Calisto en la huerta en el Auto I hasta el final del conjuro (Auto III) habría transcurrido no menos de ocho días, y entre el final del Auto III y el comienzo del IV, dos o tres días. De este modo, el tiempo no representado pero inferido del texto dialogado o «tiempo en off» abarcaría en la Comedia entre 15 días (2010 y 2017) y casi tres semanas (2018).

19.- Hemos tratado ampliamente del uso de los vocablos «autor» $y$ «auctor» en las ediciones antiguas de la Tragicomedia, tanto en la traducción al italiano de 1506 y Zaragoza 1507 como en las «falsas 1502», en nuestro artículo de 2011. Dadas las fechas de dicho estudio, quedaron fuera de él las dos "falsas 1502» descubiertas en 2017 en la Forschungsbibliothek Erfut/ Gotha y en la Biblioteca Nazionale de Nápoles. Véase José Luis Canet Vallés 2018: 53 n. 23.

20.- Patizia Botta (1999: 19) recuerda que así lo han considerado «varios hispanistas famosos, especialistas en La Celestina, desde Menéndez Pelayo hasta Martín de Riquer y Francisco Rico». Por su parte, Nicasio Salvador (1999: 14-15) resalta sus cualidades y afirma que es la edición «que mejor representa la versión definitiva». 
ginas a sus particularidades ${ }^{21}$ y es la base de la mayoría de las ediciones modernas o la que sirve para llenar lagunas de otras ediciones, no se ha prestado especial atención a este cambio que nosotros conceptuamos de gran interés porque vemos en él un factor más de la precisión que singulariza a sus paratextos, y obviamente a los de las también valencianas de 1518 y 1529, a la que siguen a plana y renglón aunque corrigiendo algunas erratas y añadiendo unos xilograbados que quieren representar a Rojas y a Alonso de Proaza. ${ }^{22}$

Juzgamos que esta modificación no es aleatoria sino que tiene la función de despejar oscuridades. Mientras que en la Comedia, el «autor» manifiesta en la Carta su decisión de callar su nombre, en el acróstico de los versos lo declara expresamente: la contradicción, o quizá la paradoja como se verá después, es evidente. En cambio, en la Tragicomedia no hay oscuridad pues quien silencia su nombre en la Carta es el "auctor», y quien lo declara en el acróstico es el «autor»: son dos personas distintas. Nos explicaremos retomando sucintamente ideas que hemos argumentado en otros trabajos $(2009,2011,2016)$.

Lo más significativo de tal cambio radica en la circunstancia de que estos dos vocablos, "auctor» $y$ "autor», pueden poseer en los primeros tiempos de la imprenta y bajo la concepción del libro impreso como producto comercial sujeto a implicaciones jurídicas, significados diferentes, según se deduce de las definiciones que aporta el Diccionario de Autoridades (DA):

Autor.- Comúnmente se llama el que escribe libros, y compone y saca a luz otras obras literarias.

Auctor.- Término forense antiguo, y corresponde al que vende alguna cosa, o traspasa alguna acción, u derecho a otro. [...] Hugo Celso [1538]: Auctor es aquel de quien alguno tiene cosa alguna, o derecho. ${ }^{23}$

21.- Pueden verse al respecto Nicasio Salvador Miguel (1999: 15), Patrizia Botta (1999: 24-29), Canet Vallés (1999: 34-38), Víctor Infantes (2007: 14-15, 85-86; 2010: 23, 89-90), Remedios Prieto y Antonio Sánchez (2016: 138-140).

22.- Reproducción y descripción de los xilograbados en Miguel Marciales I, xviii-xx, 233234 y Enrique Fernández, Celestina Visual. La mayoría de las ediciones modernas que toman por base Valencia 1514 o anotan sus variantes en el aparato crítico, bien por inadvertencia, bien por adaptarse a los usos gráficos actuales, bien por imponerlo las normas editoriales, no reproducen la diferencia gráfica entre «auctor» $\mathrm{y}$ «autor». Por ello hemos acudido a los originales. Recientemente, Canet (2017c) ha publicado la Tragicomedia utilizando como texto base el de Valencia 1518 y aunque mayoritariamente sigue criterios gráficos y ortográficos modernos, respeta la diferencia entre "auctor» $y$ «autor».

23.- Esta definición forense aplicada al ámbito puramente literario o de producción de textos puede vincularse al concepto de auctoritas, ya que, en ese caso, "auctor» alude a la fuente primigenia de algún texto o de alguna idea utilizada por un autor posterior. Por otra parte, Du Cange, en su Glossarium ad Scriptores Mediae et Infimae Latinitatis (1678), define de forma semejante el término auctor: "Auctor, apud Latinos Scriptores et IC. dicitur dominus rei, vel venditor, qui rem vendit, dominumque illius habere se profitetur, probatque. [...]». 
A partir de estas definiciones se vislumbra la posibilidad de que la obra literaria de un AUCTOR pueda ser "compuesta" y "sacada a luz" por un AUTOR. Esta posibilidad queda corroborada en la portada de la segunda edición del Cancionero General, compuesto y preparado para la imprenta por Hernando del Castillo también en Valencia y precisamente en el mismo año que la edición de la Tragicomedia origen de este comentario: "Cancionero General de muchos y diversos AUCTORES, otra vez impresso, emendado y corregido por el mismo AUTOR». El «autor» del libro es Hernando del Castillo, que lo ha compuesto y ha sacado a luz los poemas de los "auctores", poemas que fueron traspasados o cedidos con el fin de conformar el Cancionero. A la vista de todo esto, las rúbricas de la edición de Valencia — «El AUCTOR a un su amigo" para la Carta $y$ "El AUTOR escusándose de su yerro en esta obra que escribió contra sí arguye y compara» para los Versos acrósticos- designan respectivamente a dos personas diferentes: el remitente de la Carta es el AUCTOR anónimo ${ }^{24}$ que traspasa su acción, es decir, la obra literaria en estado manuscrito realizada por él, y su derecho sobre ella a su amigo para pagarle así los «beneficios "y «muchas mercedes» que ha recibido de él $;^{25}$ y quien se nombra en el acróstico es el AUTOR, que la "compone» (refunde, reelabora, "acaba» dándole la última mano) y saca a luz. Así pues, desde este enfoque crítico, el «auctor» anónimo cede, traspasa su creación y derechos a su amigo (Fernando de Rojas) quien, en posesión del manuscrito y en consonancia con las prácticas literarias y editoriales vigentes en la época, se siente facultado para intervenir en él realizando cuantas modificaciones juzga pertinentes antes de darlo a la imprenta. De esta manera, Rojas ha pasado a ser el "autor» del libro — lo que en buena parte podría coincidir con lo que hoy denominamos adaptador o editor literario-, pero no el creador/inventor de los diálogos de la obra manuscrita cedida sobre la que él intervino. La descodificación de las rúbricas conforme al contexto sociolingüístico y cultural contemporáneo sería una de las causas de que nadie en el ámbito de la cultura durante los siglos XVI-XVIII lo conceptuara de creador de la Celestina. En cambio, en el siglo XIX, tiempo en que ya se había forjado el concepto de "autor» según se entiende en la modernidad y desaparecidos los referentes socioculturales de los siglos anteriores, el nombre de Fernando de Rojas pasó a ser el del creador de la Celestina (Remedios Prieto y Antonio Sánchez 2016).

24.- Que el remitente es anónimo se desprende de la frase «Y pues él [el antiguo auctor] con temor de detractores y nocibles lenguas más aparejadas a reprehender que a saber inventar, celó su nombre, no me culpéys si en el fin baxo que le pongo no espresare el mío.» (171)

25.- «Suelen los que de sus tierras absentes se fallan considerar de qué cosa aquel lugar donde parten mayor inopia o falta padezca, para con la tal servir a los conterráneos de quien en algún tiempo beneficio recebido tienen. Y viendo que legítima obligación a investigar lo semijante me compelía para pagar las muchas mercedes de vuestra libre liberalidad recebidas $[\ldots] »(171)$ 
Ahora bien, en las ediciones de la Comedia, tanto en la rúbrica de la Carta como en la de los Versos acrósticos se escribe «EL AUTOR». Este hecho abonaría la consideración de variantes fonético-gráficas de ambos términos y que nosotros obviamos por respeto a las definiciones registradas en el $D A$ y avaladas por el Cancionero General. Y esta circunstancia nos induce a profundizar en la cuestión.

En la Comedia (que no en la Tragicomedia), en el final de la Carta de «El autor a un su amigo", el remitente anónimo había proporcionado a su amigo destinatario la siguiente información sobre su propia contribución a la obra:

E porque conozcáys dónde comiençan mis mal doladas razones y acaban las del antiguo auctor, en la margen hallaréys una cruz y es en fin de la primera cena. Vale. (172)

Como es inverosímil que en una obra impresa se coloque una cruz en el margen como dato informativo para una sola persona, que ni siquiera se nombra, y como no existe tal cruz en ninguna de las ediciones de la Comedia conservadas, esta Carta no puede ser más que la reproducción (despojada de algunos elementos y de una larga interpolación alusiva a circunstancias propias del Bachiller que precisaremos en el apartado siguiente) de la que se escribiría para acompañar a una obra manuscrita enviada a una persona concreta, acto nada inusual en la época. ${ }^{26}$ En tal caso su autor podría poner una cruz en el lugar que procediera. Además el rótulo "El AUTOR a un su amigo» resulta correcto porque hace referencia a la persona $(X)$ que había hecho su obra manuscrita tomando como base «las razones del antiguo auctor», las cuales «acabó» para enviársela a su amigo (Fernando de Rojas).También es correcta la rúbrica que antecede a los Versos acrósticos ya que alude a la persona (Fernando de Rojas) que a su vez "acabó» (compuso, refundió, dio la última mano) y "escribió» (reescribió) la obra recibida para sacarla a luz mediante la imprenta. ${ }^{27}$

26.- Era normal incluir al comienzo del libro impreso la carta que había acompañado a la obra manuscrita enviada a un amigo o protector como primicia. Como testimonios de ello valgan tres cartas: la de Pedro López de Ayala a Gonzalo de Mena enviándole su Libro de la caza de las aves, la del Marqués de Villena a Mosén Pero Pardo junto con su tratado de Los doce trabajos de Hércules, y la de Diego de San Pedro a don Diego Hernández, Alcaide de los Donceles, remitiéndole su Cárcel de Amor. Lida de Malkiel (1962: 14-15) recuerda que Juan de Vallata en carta dirigida a su protector le invita a colaborar en su comedia humanística Poliodorus enriqueciéndola con sentencias.

27.- Con esto no queremos insinuar que Rojas fuera el editor financiador de la obra. Estimamos lúcido el razonamiento de Canet (2007:47 y 2011: 29-30) acerca de la financiación económica de las primeras ediciones de la Celestina: «Pienso, pues, que la Celestina fue una propuesta intelectual en la que participaron diversos profesores e intelectuales de su tiempo, pero además algún que otro poder fáctico capaz de aportar el primer capital y renombre [...] me atrevo a aventurar que posiblemente esté detrás de esta actuación conjunta el Cardenal Cisneros $[\ldots] »$. 


\section{La Tragicomedia corrige la ausencia del "fin baxo» en la Comedia}

El remitente de la Carta dice que no incluye su nombre en el «fin baxo» que pone a la obra:

Y pues él [el «antiguo auctor] con temor de detractores y nocibles lenguas más aparejadas a reprehender que a saber inventar celó su nombre, no me culpéys si en el fin baxo que le pongo no espresare el mío. (171)

La única posibilidad de expresar el nombre de un autor al final de la obra estriba en poner un «Fin", éxplicit o texto conclusivo, donde poder incluirlo. María Rosa Lida (1962: 15-16, n. 5) recoge los nombres de Conradus y Jean Renart introducidos respectivamente al fin del tratado $D e$ disciplina scolarium y de los poemas Escoufle y Guillaume de Dôle. También cabe recordar el nombre de Per Abbat en el éxplicit del códice del Cantar de mio Cid. Y por poner un ejemplo de libro español impreso, contemporáneo de la Celestina y muy leído y editado en el siglo XVI, citaremos el de Juan de Padilla "el Cartujano", quien en el "Fin» con que cierra su obra Retablo de la vida de Cristo incluye su nombre y apellido en el acróstico de la última octava de arte mayor ([1505] 1528: fol. lxxv v)..28

Pero en la Comedia no existe ningún "Fin baxo». Al final de la Comedia solo existen seis octavas de arte mayor precedidas por la rúbrica «Alonso de Proaza, corrector de la impressión, al lector» (347-348), que, concordando con el bibliógrafo Fermín de los Reyes (2000: I, 94 n. 32), juzgamos testimonio de la censura aprobatoria para la publicación de la obra en letras de molde, ya en práctica antes de que se sancionara la Pragmática de 1502 (Antonio Sánchez y Remedios Prieto 2011: 120-122; Remedios Prieto 2014: 117-121).

La ausencia de un "fin baxo» anónimo en la Comedia hubo de ser también objeto de críticas o comentarios según se infiere del hecho de que la Tragicomedia incluya, delante de las octavas de Proaza, es decir, al final de la obra, tres nuevas octavas de arte mayor encabezadas por la advertencia "Concluye el autor aplicando la obra al propósito por que la acabó» (i $\left.{ }_{v}{ }^{r}\right)$, con lo que, ahora sí, queda materializado ese "fin baxo" anónimo inexistente en las ediciones de la Comedia, porque en estas tres estrofas finales, conclusivas, no aparece nombre alguno. En ellas, el «autor» manifiesta la intención moralizadora y cristiana que le impulsó a «acabar» la obra preexistente.

¿Existiría un «fin baxo» sin expresión de nombre alguno en la comedia manuscrita de final feliz? En trabajos publicados con anterioridad hemos

28.- «FIN» / «Don religioso la regla me puso, / jurado con voto canónico puro; / ante su vista me hallo seguro / de la tormenta del mundo confuso. / Padece, por ende, mi nombre recluso, / digno lector, si lo vas inquiriendo. / Llama si quieres mi nombre diziendo: / monje cartuxo la obra compuso.» (Transcripción de Rocío Rodríguez Ferrer 2009: 748) 
aportado diversas razones que nos permiten afirmarlo; ${ }^{29}$ ahora simplemente aplicaremos las conclusiones. Suprimamos de la serie acróstica (173-176) todas las estrofas en cuya lectura en vertical se nos ofrece el nombre, apellido, rango académico y lugar de nacimiento de Rojas. Nos quedan las cuatro estrofas centrales: 4, 5, 6 y 7 , en las que se da la particularidad de que tanto el acróstico como el contenido temático de sus versos tienen sentido pleno e independiente de los demás:

\section{El bachjller Fernando de Roya [estrofas 1-3]}

\section{Sacabó la Comedia de Calysto y Melybea [estrofas 4, 5, 6, 7]}

Y fve nascido en La Pvebla de Montalván [estrofas 8-11]

La lectura acróstica de estas cuatro estrofas dice simplemente S'ACABÓ la Comedia de Calysto y Melybea y forman por sí mismas un acróstico con sentido pleno. Si las imaginamos precedidas de la rúbrica «Fin» y colocadas inmediatamente a continuación de la obra, comprobaremos que constituyen efectivamente ese «fin baxo» anónimo prometido en la Carta. Como sugiere Cantalapiedra (2011: 62), estas estrofas funcionarían de forma semejante a los acrósticos plautinos, señalando el título de la obra y el «acabose final».

En cuanto al contenido de sus versos, estos encierran un mensaje completo: informan sobre la motivación del autor de estos para escribir su comedia de final feliz y sobre el Argumento con que esta principiaba, el juicio que le merecía la obra incompleta del "antiguo auctor», las razones que le movieron a acabarla y cómo ha realizado ese acabamiento: «imponiendo dichos lascivos rientes», "dorando con oro de lata lo más fino oro que vio con sus ojos», "sembrando abrojos encima de rosas» (esto es, que no ha realizado una transcripción exacta del escrito del «antiguo auctor», sino que lo ha reescrito) y "componiendo tal fin que el principio desata». Le dice al lector que si bien conoce el «limpio motivo» que le ha impelido a acabar la obra, lo busque en "el fin de aquesto que escribo", o sea, en los últimos versos. Si hacemos caso de la recomendación y los consultamos, nos encontraremos con ese "limpio motivo»: «Estos amantes les pornán temor / a fiar de alcahueta ni de mal sirviente» (175), motivación propia de comedia humanística corrigendo mores. También anunciaba una obra "dulce» con su correspondiente final feliz:

o del principio leed su Argumento, leeldo y veréys que, aunque dulce cuento, amantes, que os muestra salir de cativo. (174)

Esta descripción del "Argumento del principio» es verdaderamente contradictoria con lo que se percibe en el Argumento con que principia la Come- 
dia impresa que refleja la desesperación y muerte de sus personajes principales: "venieron los amantes y los que los ministraron en amargo y desastrado fin» (177). Así sabemos que la obra manuscrita que llegó a manos de Rojas fue un "dulce cuento que mostraba salir de cativo", una auténtica comedia, y que su "acabado» lo convirtió en amarga tragedia, aunque no tuvo el acierto de cambiarle el título, causa de una de las críticas de los lectores contemporáneos declarada en el Prólogo de la Tragicomedia:

Otros han litigado sobre el nombre, diziendo que no se avía de llamar Comedia, pues acabava en tristeza, sino que se llamasse Tragedia. $\left(\mathrm{a}_{\mathrm{jiii}} \mathrm{r}\right)$

Y asimismo alude a ese cambio de nombre la octava de Proaza añadida en las ediciones valencianas, precedida por la advertencia «Toca cómo se devía la obra llamar Tragicomedia y no Comedia» ( $\left.\mathrm{i}_{v} \mathrm{v}\right)$, nueva prueba de la mayor precisión de esta edición en sus paratextos.

Ciertamente, la percepción del «fin baxo» primitivo y anónimo no resulta fácil, por dos causas fundamentalmente:

- porque estas cuatro estrofas quedan embutidas, injeridas, entre las tres primeras y las cuatro últimas cuyos acrósticos ofrecen el nombre de Fernando de Rojas y sus datos identificativos.

- porque en el final de la Carta existen referencias a circunstancias personales de Rojas que inducen a pensar que la Carta y las once estrofas acrósticas fueron escritas por él:

[...] mayormente que, siendo jurista yo, aunque obra discreta, es agena de_mi facultad. Y quien lo supiesse diría que no por recreación de mi principal estudio, del qual yo más me precio, como es la verdad, lo fiziesse; antes, distraýdo de los derechos, en esta nueva lavor me entremetiesse. Pero aunque no acierten, sería pago de mi osadía. Asimismo pensarían que no quinze días de unas vacaciones, mientra mis socios en sus tierras, en acabarlo me detoviesse, como es lo cierto, pero aun más tiempo y menos accepto. Para desculpa de lo qual todo, no solo a vos, pero a quantos lo leyeren, offrezco los siguientes metros. [...] (171-172)

Estas referencias a circunstancias personales de Rojas: su condición de jurista, la consideración de la obra como «ajena de su facultad», los quince días de vacaciones y la remisión a "los siguientes metros» cuyo acróstico nos da a conocer que El bachiller Fernando de Rojas acabó la Comedia de Calisto y Melibea y fue nascido en la Puebla de Montalbán, condicionan a pensar - como es habitual en un amplio sector de la crítica especializada - que toda la Carta fue escrita por el Bachiller. Pero varios factores 
apuntan a que este fragmento está interpolado, también injerido, en la primitiva carta: rompe la natural continuidad temática del texto en que se inserta y carece del estilo humanístico y de neologismos característicos del resto de la Carta señalados por Di Camillo (2001: 111-116) y compartidos por Canet (2007: 38-39; 2017b: 33). En efecto, si suprimimos este párrafo relativo a las circunstancias personales de Rojas, se restaura la concatenación entre el párrafo que le precede y el que le sigue, quedando ambos integrados en un mismo bloque cuyo asunto se vertebra en torno al manuscrito del «antiguo auctor».

Con esta sencilla operación de cirugía consistente en anular, tanto en los Versos acrósticos como en la Carta, los datos y circunstancia personales de Fernando de Rojas, se eliminan las contradicciones existentes entre estos dos paratextos preliminares y se recupera la coherencia que debió de existir entre ellos y la comedia manuscrita de final feliz corrigendo mores.

\section{La remisión a la cruz en la Comedia se sustituye en la Tragicomedia por el comienzo del "segundo auto donde dize Hermanos míos"}

Otro arreglo en la Tragicomedia consiste en suprimir la remisión a una cruz en el margen como medio para señalar el término de las «razones del antiguo auctor» y el comienzo de las del continuador. Se leía en la Comedia:

E porque conozcáys dónde comiençan mis mal doladas razones y acaban las del antiguo auctor, en la margen hallaréys una cruz y es en fin de la primera cena. Vale. (172)

La remisión a la cruz resultaba inútil a los lectores al no encontrarla plasmada en la obra impresa. La información contigua de que se hallaba "en fin de la primera cena» tampoco resultaba eficaz, al estar la obra articulada en autos. La nueva redacción responde más a la realidad impresa:

\section{E porque conozcáys dónde comiençan mis mal doladas razo- nes, acordé que todo lo del antiguo autor fuesse sin división en un auto o cena incluso hasta el segundo auto donde dize "Her- manos míos", etc. Vale. (172 n. $\mathrm{a} ; \mathrm{a}_{\mathrm{i}}{ }^{\mathrm{v}}$ )}

En este caso, la localización no presenta ninguna dificultad y resuelve la incertidumbre anterior al equiparar "auto» $y$ «cena». Pero, como ha señalado la crítica, la identificación semántica entre "auto» $y$ "cena» es insostenible conceptual y técnicamente; por tanto, creemos necesario intentar buscar una hipótesis explicativa desde la perspectiva de nuestros postulados y otorgar al verbo "acordar» no el significado de decidir o determinar, según es habitual, sino el de concordar, ajustar, arreglar, recogido en el DA: 


\section{ACORDAR.- Vale asimismo arreglar y ajustar una cosa con otra, disponiendo que en todo sean conformes, $y$ correspondan y concuerden.}

Esta definición permite interpretar que Rojas está diciendo que concordó, que ajustó, "todo lo del antiguo autor», lo cual había constituido la "primera cena» de la comedia manuscrita de final feliz (que no estaba articulada en autos sino en escenas), con el primer auto de la obra impresa que él había preparado para que saliera a luz en letras de molde. Se comprendería así que Rojas identifique "auto» con "cena» aunque en términos de crítica literaria no sean lo mismo.

Ahora bien, tenemos justificaciones suficientes para tildar esa afirmación de falsa, inexacta o ambigua, y argumentar que "todo» lo del autor anterior no se encuentra introducido en el primer auto, dado que en él es posible detectar supresiones y desplazamientos de diálogos a otros autos, según hemos dejado constancia en estudios anteriores (1991: 65-69; 2017: 380-384, 392-394).

\section{Enmienda del "FIN" de las octavas acrósticas en la Tragicomedia}

Otra falla o inadvertencia de la Comedia, enmendada posteriormente en la Tragicomedia, se encuentra en la $4^{a}$ estrofa de la serie acróstica completa, referida a la explicitación de su «limpio motivo» para escribir la obra: "Si bien discernéys mi limpio motivo [...] buscad bien el fin de aquesto que escrivo» (174). Si consideramos solo la serie central del acróstico (que, como hemos expuesto líneas arriba estimamos procedente del «fin baxo» anónimo), tal "fin» sería: "Estos amantes les pornán temor / a fiar de alcahueta ni de mal sirviente» (175), es decir, una motivación corrigendo mores propia de las comedias humanísticas que tienen siempre final feliz.

En cambio, si consideramos la serie completa ampliada (estrofa 11), «el fin de aquesto que escribo» es este otro:

\section{FIN}

Olvidemos los vicios que así nos prendieron, no confiemos en vana esperança; temamos Aquel que espinas y lança, açotes y clavos su sangre vertieron, la su Santa Faz herida escupieron. Vinagre con hiel fue su potación, a cada santo lado consintió un ladrón, nos lleve, le ruego, con los que creyeron. (176)

Aquí no encontramos ningún «limpio motivo» conectado puntualmente a la obra, sino consejos de neto contenido cristiano centrados en la Pasión de Jesucristo. Que esta discordancia fue criticada por los lectores 
de la Comedia se refleja en la sustitución del tal «Fin» por este otro en la Tragicomedia:

\section{FIN}

O damas, matronas, mançebos, casados notad bien la vida que aquestos hizieron, tened por espejo su fin qual hovieron, a otro que amores dad vuestros cuydados.

Limpiad ya los ojos los ciegos errados, virtudes sembrando con casto bivir, a todo correr deveys de huyr, no os lance Cupido sus tiros dorados. (176 n. b; $\mathrm{a}_{\mathrm{jii}}{ }^{\mathrm{r}}$ )

de cuya lectura se infiere que, además de la inequívoca referencia de estos «metros» a la obra y su motivación, el tercer verso, «tened por espejo su fin qual hovieron", nos indica que se trata ahora de una tragedia reprobatio amoris.

Y como hemos apuntado líneas arriba, esta contraposición entre comedia y tragedia queda reflejada no solo en el Prólogo de la Tragicomedia, donde se nos informa de que el título de Comedia había sido objeto de discusiones y críticas de sus contemporáneos "pues acabava en tristeza» (a iii ${ }^{\mathrm{r}}$ ), sino también en la estrofa de Proaza añadida en las ediciones valencianas, en donde "Toca cómo se devía la obra llamar Tragicomedia y no Comedia» debido al «trágico fin que todos ovieron». $\left(\mathrm{i}_{\mathrm{v}}{ }^{\mathrm{v}}-\mathrm{v}_{\mathrm{vi}}{ }^{\mathrm{r}}\right)$.

\section{III.- Conclusión: desde el «Antiguo auctor» hasta la órbita de Cisneros}

Hemos tratado de mostrar cómo la Celestina es fruto de reelaboraciones sucesivas cuyo último "componedor» o «acabador» fue Fernando de Rojas, artífice del texto que se entrega a la imprenta y en consecuencia autor del libro y responsable de su trama argumental pero no el creador/inventor de los diálogos magníficos que reutilizó.

No se debe considerar esta práctica literaria como apropiación indebida de textos ajenos, sino consustancial a la tradición. Como hemos subrayado, los conceptos de "autor» y originalidad no eran coincidentes con los actuales. Ya desde la Edad Media, como es sabido, era usual y admisible en toda Europa la reutilización y continuación de textos ajenos reordenados y reescritos de manera que esta labor llevaba inherente una dimensión creativa.

Hay motivos para pensar que la génesis de la Celestina no fue fruto de un acto creador continuo ni mucho menos unitario ya en su versión impresa de 16 autos. No solo el Manuscrito de Palacio lo sugiere con sus variantes redaccionales (Patrizia Botta 1997; Remedios Prieto 2000 y 2001; Antonio 
Sánchez 2001; Cantalapiedra 2011 y 2016); también las aportaciones de los celestinistas citados a lo largo de estas páginas apuntan a ello.

Nuestra propuesta es que en la génesis de la obra se detectan básicamente cuatro capas o contribuciones sucesivas sometidas a un proceso de reescritura amplificadora hasta llegar a la versión Tragicomedia:

1. la del «antiguo auctor» anónimo;

2. la del segundo escritor, o autor intermedio, también anónimo, quien sobre la base de las «razones» del primero y en contacto con el humanismo italiano, hace una comedia similar a las humanísticas titulada ya "Comedia de Calisto y Melibea» de final feliz y corrigendo mores que, en estado manuscrito, cede "a su amigo" Fernando de Rojas para "pagarle las muchas mercedes recibidas» según le dice en la Carta;

3. la de Rojas, que, en «quince días de unas vacaciones», "compone», «acaba» para la imprenta dicha comedia manuscrita: la reorienta a un desenlace trágico reprobatio amoris mediante procedimientos compositivos y la reordena en 16 autos;

4. nueva intervención del Bachiller, quien en el Prólogo de la versión Tragicomedia se hace responsable de la «nueva adición» y declara haber «metido segunda vez la pluma en tan extraña labor y tan ajena de su facultad». Respondía así a las críticas de los lectores de la versión anterior en 16 autos.

Ahora bien, la reorientación de la comedia manuscrita de final feliz hacia un desenlace trágico implicaba en sí misma una moralización de la obra, moralización que, como ha evidenciado nítidamente Canet (1999; 2007; 2011: 47-96; 2017b: 40; 2018: 58-61), sintonizaba con el reformismo cristiano preconizado por Francisco Jiménez de Cisneros, su círculo lulista y la Orden Franciscana a la que pertenecía, fundamentalmente. Esta circunstancia y que la primera edición de la Comedia se publicara en Toledo (según hemos inferido en trabajos previos) nos inclinan a considerar la influencia que en ese viraje hubo de tener el entonces Arzobispo de Toledo y futuro Cardenal. Si a esto unimos la aquiescencia que supone la intervención de Proaza, persona de confianza de Cisneros, con sus elogiosas coplas que estimamos son la censura aprobatoria para poderse publicar y vender la obra según hemos defendido en estudios anteriores, ${ }^{30}$ y el hecho de que las ediciones conservadas de la Comedia fueran estampadas por impresores relacionados con Cisneros: Hagenbach, Polono y Fadrique Biel de Basilea y además con el aval del escudo real de los Reyes Católicos en las contraportadas (Canet 2014), el respaldo del Arzobispo

30.- Antonio Sánchez y Remedios Prieto 2011: 120-126; Remedios Prieto 2014: 117-121; Antonio Sánchez 2014: 138-140. En estos mismos estudios hemos defendido que la edición prínceps de la Comedia es la toledana. 
de Toledo al «acabado» de Rojas e incluso a la financiación de las primeras ediciones como apunta Canet $(2011,2014,2018)$, cobra aires de certeza. A esto se suman las ediciones de la Tragicomedia de Zaragoza 1507 y Valencia 1514, publicadas ambas en el Reino de Aragón, cuya máxima autoridad eclesiástica era el obispo de Tarazona y Canciller de Valencia don Guillén Ramón de Moncada, vinculado por amistad e ideología luliana con Proaza y el Cardenal Cisneros (Canet 1999 y 2011: 27-30; Antonio Sánchez y Remedios Prieto 2011:120-127).

Las octavas de arte mayor de Proaza, sobre todo las de las Tragicomedias valencianas, revelan su vínculo con Rojas y su obra. Proaza se muestra enterado del proceso textual de la Comedia: sabe que el «muy dulce y breve tratado» de final feliz que "mostraba salir de cativo» fue "acabado» en Salamanca por Rojas ("aqueste grand hombre») reconvirtiéndolo en otro con muy amargo desenlace mediante «el trágico fin que todos ovieron»; y declara que él mismo lo revisó y corrigió leyéndolo y puntándolo "con gran vigilancia». ${ }^{31}$

Por otra parte, cabe presuponer cierta relación entre Cisneros y Rojas. Rojas no era literato sino un joven estudiante de Leyes que obviamente conocía los enfrentamientos ideológicos que en la Universidad protagonizaban los renovadores - lulistas y humanistas - y los conservadores -tomistas y escolásticos- (Canet 2011: 47-54), y que había "nacido en La Puebla de Montalbán", esto es, en la archidiócesis de Cisneros. Además, su «acabado» no le supuso una satisfacción plena sino que fue más bien fuente de sinsabores y críticas en su contra, a juzgar por lo que dice en la tercera estrofa de los Versos acrósticos: «a mí están cortando reproches, revistas y tachas».

Por tanto, si, como todo conduce a pensar, Cisneros tuvo influencia en esa acción de Rojas consistente en moralizar cristianamente la comedia humanística preexistente "metiendo la pluma en tan extraña labor» y tan «ajena de su facultad», es lógico estimar que tratara de compensarle de alguna forma. Y la condición de jurista del Bachiller y la existencia de una villa importante perteneciente al Señorío Arzobispal de Toledo como lo era Talavera de la Reina brindaban la solución adecuada: el nombramiento de este como Alcalde Mayor, cargo que le facultaba para ejercer justicia en dicha Villa y su Tierra. Y así resulta de pura lógica:

- que existan documentos fechados en Talavera con su nombre e incluso su firma (Inés Valverde 1992; Pedro Correa do Lago 2007: 4849; Rafael Gómez 2019) vinculándole únicamente con su actividad como jurista profesional y no con la Celestina;

31.- Estas labores eran propias de los censores. Como es sabido, los censores apuntaban en los márgenes de los manuscritos observaciones, tachaban, sustituían, etc. Por ejemplo, puede verse al respecto Héctor Urzáiz Tortajada (2015). 
- que en Talavera viviera tan apartado de cualquier actividad literaria como cercano al franciscanismo, según se deduce de los deseos que expresó en su testamento: ser enterrado con hábito San Francisco en la iglesia del monasterio de monjas franciscanas de la Madre de Dios y que los frailes de San Francisco oficiaran 83 misas por su alma (Valle Lersundi 1929: 368-369);

- que los libros que poseía (Infantes 2010: 105-168) no justifiquen los amplios conocimientos literarios que acreditan los diálogos de la Celestina, y en cambio sí conecten con el sentido cristiano que emana de ella, tales Retablo de la vida de Cristo, Evangelios y Epístolas, Flos santorum o Confesionario.

- que solo se vincule su nombre a la Celestina en procesos judiciales de parientes y descendientes cuando quieren probar su ortodoxia religiosa o hidalguía y que se haga expresamente mediante el verbo "componer»: "que compuso a Melibea», "que compuso a Celestina», «que compuso el libro de Celestina» o "que compuso Celestina la Vieja» (Nicasio Salvador 2001: 25, 28, 42).

Así pues, la labor de Rojas en el terreno literario carecía de peso como para considerarle creador de la Celestina. Recordemos que en un centenar de ediciones en español y en otros idiomas entre los siglos XVI-XVIII no se imprime su nombre en las portadas, ni ningún literato ni comentarista de la Celestina lo nombra (Snow 1999-2000, 2005-2006). Y no olvidemos tampoco que, aunque la palabra "autor» aparece en las rúbricas de los paratextos de la obra, su significado no era necesariamente el actual, sino próximo al que hoy día tienen los términos «adaptador» o «editor literario» (Remedios Prieto y Antonio Sánchez 2016).

\section{Bibliografía citada}

ALCALÁ IBERRI, María del Socorro (ed.) (2013), La Celestina. Fernando de Rojas, México, Selector, "Clásicos juveniles».

ALONSO, Eduardo (ed.) (2016, 13 reimpresión), La Celestina, Barcelona, Vicens Vives, "Clásicos adaptados».

ARAGÜÉS ALDAZ, José (2014), "La difusa autoría del Flos Sanctorum. Silencios, presencias, imposturas», en Maud le Guellec (ed.), El autor oculto en la Literatura Española, Madrid, Casa de Velázquez, pp. 21-39.

BASTIANES, María (2017), «De La Celestina de Rojas a la adaptación de Alejandro Casona. Un estudio comparativo", eHumanista 35, pp. 238-256.

BATAILLON, Marcel (1961), 'La Cèlestine' selon Fernando de Rojas, Paris, Didier. 
BERNALDO DE QUIRÓS MATEO, José Antonio (2005), «Comentarios a la hipótesis de García-Valdecasas sobre la gestación de La Celestina», Espéculo 30, pp. 1-23.

- (2008), "Sobre el papel de Rojas en la elaboración de La Celestina», Lemir 12, pp. 325-340.

- (2009), "La Celestina desde el punto de vista escénico. Consecuencias para la atribución de la autoría», Lemir 13, pp. 97-108.

- (2010), Comedia de Calisto y Melibea. Hacia La Celestina anterior a Fernando de Rojas, Madrid, Manuscritos.

- (2011), "La Celestina: adiciones primeras amplificadas con adiciones segundas. Consecuencias para la atribución de la autoría», Etiópicas 7 , pp. 87-104.

- (2012), «Efectos provocados en la Comedia de Calisto y Melibea por las adiciones primeras. Una clasificación», Etiópicas 8, pp. 172-199.

- (2015), «Sentencias y refranes en la hipotética Celestina primitiva», Tonos Digital 28, pp. 1-22.

- (2017) La Celestina primitiva. Restauración del texto original, anterior a los desaciertos de Fernando de Rojas, Madrid, Liceus.

BOTTA, Patrizia (1997), "El texto en movimiento (De La Celestina de Palacio a La Celestina posterior)", en Rafael Beltrán y José Luis Canet (eds.), Cinco siglos de Celestina: aportaciones interpretativas, Valencia, Universitat de València, pp. 135-147.

- (1999), "El texto de La Celestina en la edición de Valencia, 1514», en Tragicomedia de Calisto y Melibea (Valencia, Juan Joffre 1514) Estudios y edición paleográfica y facsimilar, eds. Nicasio Salvador Miguel y Santiago López-Ríos, Valencia, Institució Alfons el Magnànim, vol. I, pp. 17-29.

- (2007), «El paso de la Comedia a la Tragicomedia», en Juan Carlos Conde (ed.), Actas del Simposio Internacional 1502-2002: Five Hundred Years of Fernando de Rojas" "Tragicomedia de Calisto y Melibea" (18-19 de octubre de 2002, Departamento de Español y Portugués, Indiana University, Bloomington), New York, Hispanic Seminary of Medieval Studies, pp. 91-113.

BUSTOS TAULER, Álvaro (2012), «Del Actor deste libro»: Sobre el Cancionero de la Biblioteca Británica (LB1) y el de Juan del Encina (96JE)», Revista de Cancioneros Impresos y Manuscritos 1, pp. 41-78.

CANET VALLÉS, José Luis (1999), "Alonso de Proaza", en Tragicomedia de Calisto y Melibea (Valencia, Juan Joffre 1514) Estudios y edición paleográfica y facsimilar, eds. Nicasio Salvador Miguel y Santiago López-Ríos, Valencia, Institució Alfons el Magnànim, vol. I, pp. 31-38.

- (2007), «Celestina: 'sic et non'. ¿Libro escolar-universitario?», Celestinesca 31, pp. 23-58.

- (2008), "La Celestina en la 'contienda' intelectual y universitaria de principios del siglo XVI», Celestinesca 32, pp. 85-107. 
CANET VAllÉS, José Luis (ed.) (2011), Comedia de Calisto y Melibea, edición crítica, introducción y notas. Valencia, Universitat de València.

- (2014), "A vueltas con las ediciones de la Comedia de Calisto y Melibea», en Texto, edición y público lector en los albores de la imprenta, eds. Marta Haro Cortés y José Luis Canet, Valencia, Universitat de València, pp. 53-82.

- (2017a), "La edición burgalesa de la Comedia de Calisto y Melibea: ¿manipulación lucrativa de su fecha de impresión?», eHumanista 35, pp. 408- 438.

- (2017b), "The Early Editions and the Authorship of Celestina», en $A$ Companion to Celestina, ed. Enrique Fernández, Leiden-Boston, Brill, pp. 21-40.

- (ed.) (2017c), La Celestina (Tragicomedia de Calisto y Melibea). ¿Fernando de Rojas?, Würzburg-Madrid, Clásicos Hispánicos.

- (2018), "De Nuevo sobre la autoría de La Celestina», Letras 77 (Studia Hispanica Medievalia XI, Actas de las XII Jornadas Internacionales de Literatura Española Medieval «La Celestina y lo celestinesco. Homenaje al Profesor Joseph Thomas Snow»), pp. 35-68.

CANTALAPIEDRA EROSTARBE, Fernando (1979), Pour une analyse sémiotique de La Célestine de F. de Rojas, Thèse de III cycle. Université de Paris III, Sorbonne.

- (ed.) (2000), Anónimo / Fernando de Rojas. Tragicomedia de Calisto y Melibea. Edición crítica, con un estudio sobre la autoría y la «Floresta celestinesca», Kassel, Reichenberger.

- (2001), "Sentencia petrarquistas y adiciones a la Tragicomedia de Calisto y Melibea», en Tras los pasos de "La Celestina», eds. Patrizia Botta, Fernando Cantalapiedra, Kurt Reichenberger y Joseph T. Snow, Kassel, Reichenberger, pp. 55-154.

- (2006), "Alisa y Celestina. Las comadres de las tenerías», en Isabel Sancho, Lourdes Ruiz \& Francisco Gutiérrez eds. Estudios sobre la Lengua, Literatura y Mujer. Jaén, Universidad de Jaén, pp. 63-130.

CANTALAPIEDRA EROSTARBE, Fernando (2011), "Fue tanto breve quanto muy sutil. Los paratextos de La Celestina», eHumanista 19, pp. 20-78.

- (2016), "Notas sobre el Manuscrito de Palacio-1520, adiciones marginales y controversias filológicas", Celestinesca 40, pp. 9-52.

CORREA DO LAGO, Pedro (2007), Cinco siglos en papel. Autógrafos y manuscritos de la colección Pedro Correa do Lago, San Sebastián, Nerea.

DI CAMILLO, Ottavio (2001), "La péñola, la pluma y la doladera. Tres formas de cultura humanística en la Carta 'El autor a un su amigo' de La Celestina», en Silva. Studia philologica in honorem Isaías Lerner, ed. de Isabel Lozano y Juan Carlos Mercado, Madrid, Castalia, pp. 111-126. 
DI CAMILLO, Ottavio (2010), «When and Where was the First Act of $L a$ Celestina composed? A Reconsideration", en 'De ninguna cosa es alegre posesión sin compañia'. Estudios celestinescos y medievales en honor del profesor Joseph Thomas Snow, I, coord. Devid Paolini, New York, Hispanic Seminary of Medieval Studies, pp. 91-157.

- (2012), "Algunas consideraciones sobre La Celestina italiana», en Patrizia Botta (coord.), Rumbos del hispanismo en el umbral del Cincuentenario de la AIH, II, Roma, Bagatto Libri, pp. 216-226.

ESCOBAR, Luis y Humberto PÉREZ DE LA OSSA (adaps.) (1959), La Celestina, Madrid, [S. n.]

FERNÁNDEZ, Enrique (1997), "Una forma no lineal de leer Celestina: el compendio de sententiae como mapa textual», Celestinesca 21, pp. 31-47.

-, Celestina Visual. <http://celestinavisual.org/>.

FOULCHÉ-DELBOSC, Raymond (1900), "Observations sur la Célestine», Revue Hispanique VII, pp. 28-80.

GARCI-GÓMEZ, Miguel (1994), Calisto: soñador y altanero, Kassel, Reichenberger.

GARCÍA-VALDECASAS, José Guillermo (2000), La adulteración de "La Celestina", Madrid, Castalia.

GERLI, E. Michael (1995), "Complicitous Laughter: Hilarity and Seduction in Celestina", Hispanic Review 16, pp. 19-38.

GÓMEZ, Rafael (2019), "Aparece por primera vez la firma de Fernando de Rojas», Archivo Municipal de Talavera de la Reina.

GÓMEZ GOYZUETA, Ximena (2017), «El encuentro imposible entre Celestina y Alisa: una lectura mediante el adynaton", eHumanista 37, pp. 669-679.

HIREL-WOUTS, Sophie, (2017), «Una continuación polémica: el Tratado de Centurio en la Tragicomedia de Calisto y Melibea», en David Álvarez Roblin y Olivier Biaggini (ed.), La escritura inacabada. Continuaciones literarias y creación en España. Siglos XIII a XVII, Madrid, Casa de Velázquez, pp. 51-68.

INFANTES, Víctor (2010), La trama impresa de Celestina. Ediciones, libros y autógrafos de Fernando de Rojas, Madrid, Visor Libros, pp. 11-103.

LIDA DE MALKIEL, María Rosa (1962), La originalidad artística de "La Celestina", Buenos Aires, EUDEBA.

LACARRA LANZ, María Eugenia (ed.) (1990), Fernando de Rojas. "La Celestina». Introducción y notas. Barcelona, Ediciones B.

LOBERA, Francisco J., SERÉS, Guillermo; DÍAZ-MAS, Paloma; MOTA, Carlos; RUIZ ARZÁLLUZ, Íñigo; RICO, Francisco (eds.) (2000), Fernando de Rojas (y "antiguo autor»). "La Celestina. Tragicomedia de Calisto y Melibea", Barcelona, Crítica. Reimpreso en 2011, Madrid, Real Academia Española, Biblioteca Clásica de la Real Academia Española.

LÓPEZ MORALES, Humberto (ed.) (1995), Fernando de Rojas. "La Celestina», Barcelona, RBA Editores. 
MARCIALES, Miguel (ed.) (1985), Celestina. Tragicomedia de Calisto y Melibea. Fernando de Rojas. Al cuidado de Brian Dutton \& Joseph T. Snow. Urbana y Chicago, University of Illinois Press, 2 vols.

MENÉNEZ PELAYO, Marcelino [1910] (1962, $2^{\mathrm{a}}$ ed.), Orígenes de la novela, III, Madrid, CSIC. Biblioteca Virtual Miguel de Cervantes.

MIGUEL MARTÍNEZ, Emilio de (1996), La Celestina de Rojas, Madrid, Gredos.

PADILLA, Juan de [1505] (1528), Retablo de la vida de Cristo, Sevilla, Jacobo Cromberger.

PAOLINI, Devid (2011), «Sobre un tópico equivocado (las representaciones de las comedias de Plauto y Terencio en España a finales del siglo xv) y Celestina», Celestinesca 35, pp. 67-84.

- (2012) "La comedia humanística, La Celestina y España», en Patrizia Botta coord. Rumbos del hispanismo en el umbral del Cincuentenario de la Asociación Internacional de Hispanistas. Roma, Bagatto Libri, Vol. 2, pp. 281-287. Centro Virtual Cervantes.

- (2017), "Algunas observaciones sobre el problema de la génesis de Celestina», eHumanista 35, pp. 362-368.

PARRILLA, Carmen (2007), "Incremento y raciocinio en la Tragicomedia», en Actas del Simposio Internacional 1502-2002: Five Hundred Years of Fernando de Rojas' "Tragicomedia de Calisto y Melibea" (18-19 de octubre de 2002, Departamento de Español y Portugués, Indiana University, Bloomington), ed. de Juan Carlos Conde, New York: Hispanic Seminary of Medieval Studies, 2007, pp. 227-239.

PENNEY, Clara Louisa (1954), The Book Called "Celestina" in the Library of the Hispanic Society of America, New York, Hispanic Society.

PERROMAT AUGUSTÍN, Kevin (2009), "Cuervos, cornejas y plumas ajenas. Autoría difusa y reutilización de materiales en el teatro del Siglo de Oro", Lemir 13, pp. 261-280.

PRIETO DE LA IGLESIA, Remedios (1994), «Las piezas preliminares de La Celestina: un mensaje comunicacional», en Actas del III Congreso de la Asociación Hispánica de Literatura Medieval (Salamanca, 3 al 6 de octubre de 1989), II. Edición al cuidado de María Isabel Toro Pascua, Salamanca, Biblioteca Española del Siglo xv, pp. 797-803.

PRIETO DE LA IGLESIA, Remedios (2000), "Reflexiones sobre el íncipit y la portada de las ediciones de la Comedia de Calisto y Melibea y el Manuscrito de Palacio", Celestinesca 24, 1-2, pp. 57-67.

- (2001), "La portada de las ediciones de la Comedia y el Manuscrito 1520 de Palacio: evolución textual de La Celestina». En Felipe B. Pedraza, Rafael González Cañal \& Gema Gómez Rubio eds. La Celestina. V Centenario (1499-1999). Actas del Congreso Internacional Salamanca, Talavera de la Reina, Toledo, La Puebla de Montalbán, 27 de septiembre a 1 de octubre de 1999. Cuenca, Universidad de Castilla-La Mancha, 2001, pp. 283-291. 
PRIETO DE LA IGLESIA, Remedios (2014), «Erratas y corrector de la impresión: Alonso de Proaza y Celestina», Celestinesca 38, pp. 113-124.

- y Antonio SÁNCHEZ SÁNCHEZ-SERRANO (2016), "Posibles razones por las que la Celestina fue considerada anónima durante los siglos XVIXVIII y creación de Rojas a partir del XIX», Celestinesca 40, pp. 135-158.

- y Antonio SÁNCHEZ SÁNCHEZ-SERRANO (2017), «Leyendo analíticamente la Celestina. Huellas en sus diálogos de la trama argumental de una comedia precedente», eHumanista 35, pp. 377-407.

REYES GÓMEZ, Fermín (2000), El libro en España y América. Legislación y Censura (siglos XV-XVIII) I, Madrid, Arco/Libros, Instrumenta Bibliologica. RODRÍGUEZ FERRER, Rocío (ed.) (2009), Retablo de la vida de Cristo, de Juan de Padilla, El Cartujano: estudio y edición crítica. Tesis doctoral.

RUBIO GARCÍA, Luis (1985), Estudios sobre "La Celestina», Murcia, Universidad de Murcia, Departamento de Filología Románica.

RUSSELL, Peter E. (1978), "La magia, tema integral de La Celestina», en Temas de "La Celestina" y otros estudios, trad. de Alejandro Pérez, Barcelona, Ariel, pp. 241-276. Biblioteca Virtual Miguel de Cervantes.

- (1988), "Discordia universal: La Celestina como floresta de philosophos», Ínsula 497, pp. 1 y 3.

SALVADOR MIGUEL, Nicasio (1999), "Fernando de Rojas y La Celestina», en Tragicomedia de Calisto y Melibea (Valencia, Juan Joffre 1514) Estudios y edición paleográfica y facsimilar, eds. Nicasio Salvador Miguel y Santiago López-Ríos, Valencia, Institució Alfons el Magnànim, vol. I, pp. 7-15.

- (2001), «La identidad de Fernando de Rojas» en Felipe B. Pedraza, Rafael González Cañal y Gema Gómez Rubio (eds.), La Celestina. V Centenario (1499 Salamanca-1999). Actas del Congreso Internacional Salamanca, Talavera de la Reina, Toledo, La Puebla de Montalbán, 27 de septiembre a 1 de octubre de 1999, Cuenca, Universidad de Castilla-La Mancha, pp. 23-47. SÁNCHEZ SÁNCHEZ-SERRANO, Antonio [1985] (1987), Mensaje de "La Celestina». Análisis de un proceso de comunicación diferida (Departamento de Lingüística y Literatura, Facultad de Ciencias de la Información), Madrid, Universidad Complutense, col. Tesis Doctorales.

SÁNCHEZ SÁNCHEZ-SERRANO, Antonio (1994), "Diálogos interpolados o refundidos en la Comedia de Calisto y Melibea», en Actas del III Congreso de la Asociación Hispánica de Literatura Medieval (Salamanca, 3 al 6 de octubre de 1989), II. Edición al cuidado de María Isabel Toro Pascua, Salamanca, Biblioteca Española del Siglo xv, Departamento de Literatura Española e Hispanoamericana, pp. 805-812.

- (2001), "Otro punto de vista sobre el Manuscrito de Palacio Ms. 1520", en Felipe B. Pedraza, Rafael González Cañal \& Gema Gómez Rubio eds. "La Celestina». V Centenario (1499 Salama-1999). Actas del Congreso Internacional Salamanca, Talavera de la Reina, Toledo, La Puebla de Montalbán, 27 de septiembre a 1 de octubre de 1999. Cuenca, Universidad de Castilla-La Mancha, pp. 273-281. 
SÁNCHEZ SÁNCHEZ-SERRANO, Antonio (2014), «Las abreviaturas en cuatro ediciones tempranas de la Celestina: Toledo 1500, Burgos 14991502 (?), Zaragoza 1507 y Valencia 1514. Catalogación, cuantificación y consecuencias editoriales», Celestinesca 38, pp. 125-154.

- y Remedios PRIETO DE LA IGLESIA (1971), Solución razonada para las principales incógnitas de "La Celestina», Madrid, Edición de los autores.

- y Remedios PRIETO DE LA IGLESIA (1989), «Fernando de Rojas acabó la Comedia de Calisto y Melibea», Revista de Literatura LI, 101, pp. 21-54.

- y Remedios PRIETO DE LA IGLESIA (1991), Fernando de Rojas y "La Celestina», Barcelona, Teide, «El escritor y su literatura».

- y Remedios PRIETO DE LA IGLESIA (2009), «Sobre la 'composición' de la Celestina y su anónimo 'auctor'”, Celestinesca 33, pp. 143-171.

- y Remedios PRIETO DE LA IGLESIA (2011), “'Auctor', 'autor' y otros problemas semánticos concernientes a la autoría, gestación y ediciones de la Celestina», Celestinesca 35, pp. 85-136.

SEVILLA ARROYO, Florencio (2009), «Amor, magia y tiempo en La Celestina», Celestinesca 33, pp. 173-216.

SNOW, Joseph T. (1999-2000), "Fernando de Rojas, ¿autor de Celestina?», en Studia Hispanica Medievalia V. Actas de las VI Jornadas Internacionales de Literatura Española Medieval, eds. A. Liotta \& S. Lupi, Letras 40-41, pp. 152-157.

— (2001), «Los estudios celestinescos 1999-2099», en «La Celestina». V Centenario (1499-1999), Actas del Congreso Internacional Salamanca, Talavera de la Reina, Toledo, La Puebla de Montalbán, 27 de septiembre a 1 de octubre de 1999, eds. Felipe B. Pedraza Jiménez, Rafael González Cañal y Gema Gómez Rubio, Cuenca, Universidad de Castilla-La Mancha, pp. 121-130.

- (2005-2006), "La problemática autoría de Celestina», Íncipit 25-26, pp. 537-561.

- (2010), "Celestina y el concepto de tiempo dramático», en Expresiones de la cultura y el pensamiento medievales, eds. L. von der Wal de Moheno, C. Company y A. González (Publicaciones de Medievalia n. 37. México D. F., El colegio de México, UNAM, UAM, 19-39.

- (2017), "La metamorfosis de Melibea en la Tragicomedia de Calisto y Melibea", Celestinesca 41, pp. 153-166.

- (2018), «La cuestión peliaguda del tiempo en Celestina: propuesta de acotaciones escénicas», Celestinesca 42, pp. 269-290.

STAMM, James R. (1985), La estructura de "La Celestina", Salamanca, Universidad de Salamanca, Secretariado de Publicaciones.

TORRENTE BALLESTER, Gonzalo (adap.) (1988), Fernando de Rojas. "La Celestina", Madrid, Ministerio de Cultura, Instituto Nacional de las Artes Escénicas y de la Música.

Tragicomedia de Calisto y Melibea (1514), Valencia, Juan Joffre (Biblioteca Nacional de España: R/4870. Biblioteca Virtual Miguel de Cervantes). 
Tragicomedia de Calisto y Melibea (1518), Valencia, Juan Joffre (British Library: C.64.d.4).

Tragicomedia de Calisto y Melibea (1529), Valencia, Juan Viñao (British Library: C.63.f.).

URZÁIZ TORTAJADA, Héctor (2015), «Hagiografía y censura en el teatro clásico", Revista de Literatura 153, pp. 47-73.

VALVERDE AZULA, Inés (1992), "Documentos referentes a Fernando de Rojas en el Archivo Municipal de Talavera de la Reina, Celestinesca 16.2, pp. 81-103.

VALLE LERSUNDI, Fernando del (1929), «Testamento de Fernando de Rojas, autor de La Celestina", Revista de Filología Española XVI, pp. 367-383.

VASVARI, Louise (2009), "Glosses on the vocabu(r)lario de La Celestina", en Joseph T. Snow \& Roger Wright eds., Late Medieval Spanish Studies in Honour of Dorothy Sherman Severin, Liverpool, University Press, pp. 170-181.

VIAN HERRERO, Ana (1990), "El pensamiento mágico en Celestina, 'instrumento de lid o contienda'», Celestinesca 14.2, pp. 41-91.

VILA SELMA, José (adap.) 1967, La Celestina de Fernando de Rojas, director Eduardo Fuller. Una producción de Teatro de Siempre para TVE. celestinavisual.org/collections/show/34

WESTERVELD, Govert (2005-2009), Los tres autores de "La Celestina». El judeoconverso Juan Ramirez de Lucena, sus hijos Fernando de Rojas (Lucena) y Juan del Encina (alias Bartolomé Torres Naharro y Francisco Delicado), Murcia, Academia de Estudios Humanísticos de Blanca, 4 vols.

- (2013), Tres autores de "La Celestina». Alonso de Cardona, Juan del Encina y Alonso de Proaza, Murcia, Academia de Estudios Humanísticos de Blanca.

WHINNOM, Keith (ed.) (1983), Diego de San Pedro. Obras completas, II. Cárcel de Amor, Madrid, Castalia. 